\title{
HYDROGEOCHEMISTRY OF COASTAL CARBONATE AQUIFER IN LUCIJA-PORTOROŽ (GULF OF TRIESTE, NORTHERN ADRIATIC SEA, SLOVENIA)
}

\author{
HIDROGEOKEMIJA PRIOBALNEGA KARBONATNEGA \\ VODONOSNIKA V LUCIJI PRI PORTOROŽU (TRŽAŠKI ZALIV, \\ SEVERNO JADRANSKO MORJE, SLOVENIJA)
}

\author{
Mihael BRENČIČ
}

\begin{abstract}
UDC 556.34.06(497.4)

Mihael Brenčič: Hydrogeochemistry of coastal carbonate aquifer in Lucija-Portorož (Gulf of Trieste, northern Adriatic Sea, Slovenia)

The $801 \mathrm{~m}$ deep artesian borehole Lu-1 in Lucija near Portorož (SW Slovenia) was drilled in 1994 on the coast. The borehole is constructed in flysch in the upper $257 \mathrm{~m}$ and continues in limestone below that depth. The groundwater has a very distinct chemistry. High concentrations of iron $(10.4 \mathrm{mg} / \mathrm{l})$, sulphide $(15 \mathrm{mg} / \mathrm{l})$, and chloride $(6700 \mathrm{mg} / \mathrm{l})$ are representative showing that mixing of seawater (31\%) and groundwater (69\%) under highly reducing conditions is present in the confined carbonate aquifer. Groundwater flow is extensive and deep, fed by higher elevation precipitation to the northeast.

Keywords: salt-water intrusion, groundwater-seawater interactions, groundwater discharge, confined limestone aquifer, Lucija, Slovenia.
\end{abstract}

\begin{abstract}
Povzetek
UDK 556.34.06(497.4) Mihael Brenčič: Hidrogeokemija priobalnega karbonatnega vodonosnika $v$ Luciji pri Portorožu (Tržaški zaliv, severno Jadransko morje, Slovenija)

V letu 1994 je bila v Luciji pri Portorožu (JZ Slovenija) izvrtana $801 \mathrm{~m}$ globoka vrtina Lu-1, ki leži v neposredni bližini morja. Vrtina je v zgornjem delu do globine $257 \mathrm{~m}$ izvedena v terciarnih flišnih kamninah, $\mathrm{v}$ spodnjem delu pa $\mathrm{v}$ paleocenskih in krednih apnencih. Podzemna voda v vrtini ima zelo pester kemizem. Prisotne so visoke koncentracije železa (10,4 mg/l), sulfida (15 mg/l) in klorida (6700 mg/l), kar kaže na mešanje morske vode $(31 \%)$ in podzemne vode $(69 \%)$ pod vplivom redukcijskih pogojev v hidrodinamsko zaprtem karbonatnem vodonosniku. Opraviti imamo $\mathrm{z}$ obsežnim in globokim tokom podzemne vode, ki se napaja s padavinami na območju severovzhodnega sredogorja na razdalji več kot $10 \mathrm{~km}$.

Ključne besede: vdor morske vode, mešanje morske in podzemne vode, iztok podzemne vode, zaprt karbonatni vodonosnik, Lucija, Slovenija.
\end{abstract}

\section{INTRODUCTION}

Coastal areas are usually very densely populated and industrial activities, services, and tourist facilities are very well developed. For these reasons, demand for drinking water and other water usages is high. Demand is also present for geothermal water that can be used for heating as well as for balneological uses.
In coastal areas groundwater usage and seawaterfreshwater interaction are among the key hydrogeological problems. A short overview of the problem is given by Todd and Mays (2005), and hydrodynamical calculations regarding the saline-freshwater interface can be found in Bear (1979). For coastal karstic areas, a recent

Department of Geology, Faculty of Natural Sciences and Engineering, University of Ljubljana, Aškerčeva ulica 12, Ljubljana, Slovenia, e-mail: mihael.brencic@ntf.uni.lj.si

Department of Hydrogeology, Geological Survey of Slovenia, Dimičeva ulica 14, Ljubljana, Slovenia

Received/Prejeto: 16.04.2009 
overview is given by Fleury et al. (2007); however several review works about karstic groundwater in coastal areas can be found elsewhere (e.g. Breznik 1998; Calaforra 2004; Tulipano et al. 2005; Breznik \& Steinman 2008). Karstification of carbonate rocks from the Dinaric carbonate platform along the Adriatic coast is relatively deep and karstic features, especially submerged springs (e.g. Kuščer 1950; Kuščer \& Kuščer 1964; Bonacci 1995; Fistanić 2006) and caves (e.g. Vrhovec et al. 2001; Surić et al. 2007) can be found below the present sea level. Today they can be found from the Gulf of Trieste in North Italy to the coasts of Albania in the south (Breznik 1973). Groundwater discharges into the Slovene littoral zone are not well known. Carbonates outcrop only in the area of Izola; other parts are covered by flysch rocks (Pleničar et al. 1973). There are several indications that groundwater flow is significant (Lapanje \& Prestor 2003; Petric et al. 2004) and that submerged springs are present (Ur- banc et al. 2004; Žumer 2004, 2008; Faganeli et al. 2005); however there is no systematic knowledge about the hydrogeology of the wider Slovene coastal area.

Drinking water supply problems are profound in the Slovene coastal area. For these reasons, many practical hydrogeological investigations have been performed in the past; they were focused on drinking water supply and into low enthalpy geothermal groundwater usage. Many boreholes and wells were constructed and hydrogeology data obtained. Unfortunately, they are mainly not systematized or published. The aim of this article is to present hydrogeochemical characteristics and hydrogeological interpretations of the groundwater flow captured in the borehole Lu-1 positioned in the coastal carbonate aquifer of the Slovene coast. Data from borehole Lu-1 are compared with those for groundwater sampled in the wider Portorož (SW Slovenia) environs.

\section{SITE DESCRIPTION}

Borehole Lu-1 is positioned south of Lucija, on the western part of the land that belongs to marine Marina Lucija (Fig. 1). The shortest distance between the borehole and the sea is $40 \mathrm{~m}$ and the top of the borehole tubing is at $2 \mathrm{~m}$ a.s.l. In the near vicinity of the borehole to its north, natural streams conducts surface water from the coastal hinterland into the sea. Water in the channel is brackish with chemistry depending on the tidal conditions. South of the borehole, abandoned saltpans at Fazan are present.

Understanding the geological structure of the area is very important for the interpretation of regional groundwater flow. The southwest area of Slovenia representing the maritime province is composed of Eocene flysch and transitional marl overlying the rocks of the Adriatic Dinaric carbonate platform which spans the Upper Triassic to the alveoline nummulite limestone of the Middle Eocene age. The area is located on the border between Istria belonging to the Dinaric foreland and Čičarija and Kras that belong to the External Dinarides. Thrust faults are present in the area that were activated post Miocene due to underthrusting of Istria beneath the External Dinarides. The thrust belt strikes generally NW-SE dipping toward NE. Thrust blocks consist of limestone and flysch rocks that alternate in the direction of dip (Placer 1981, 2005, 2007).

The borehole was completed to the depth of $801 \mathrm{~m}$. To the depth of $23 \mathrm{~m}$, the borehole is drilled in Quaternary organic clay sediments. In the interval between
$23 \mathrm{~m}$ and $128 \mathrm{~m}$ in depth, interbeded marl and sandstone within flysch of Eocene age is present. In the interval between the depths of 128 and $257 \mathrm{~m}$ marls are intercepted; their upper part is Eocene and their lower part is Palaeocene age. These beds are followed by Palaeocene alveoline-nummulite limestone extending to a depth of $378 \mathrm{~m}$. In its upper part pyrite lenses several millimetres in thickness are present. In the interval between 378 and $381 \mathrm{~m}$ clay with coal is found (Fig. 2). In the same beds, Sečovlje coal mine operated in the vicinity (Breznik 1973; Plenčar et al. 1973). From $381 \mathrm{~m}$ to the final depth of $801 \mathrm{~m}$ massive upper Cretaceous limestone with dark nearly black bituminous beds intercalated with white sparitic layers is found. Limestone joints are filled with calcite and thin films of iron minerals. Below $500 \mathrm{~m}$, no open fissures conducting water were observed.

From the surface to a depth of $244.5 \mathrm{~m}$ the borehole is cased with concrete. From $244.5 \mathrm{~m}$ to the final depth the borehole is open without any casing. The borehole was drilled with reverse borehole fluid circulation. Water in the aquifer was pushed out together with drilling cuttings through the tubing with compressed air blown into the annulus space between tubing and casing. After the drilling was completed, the temperature at the casing mouth was $23^{\circ} \mathrm{C}$ and the temperature at the bottom under static no flow conditions was $28^{\circ} \mathrm{C}$.

Groundwater hydrogeochemistry from borehole Lu-1 has been interpreted considering chemical analyses from other boreholes, springs, and surface water in 


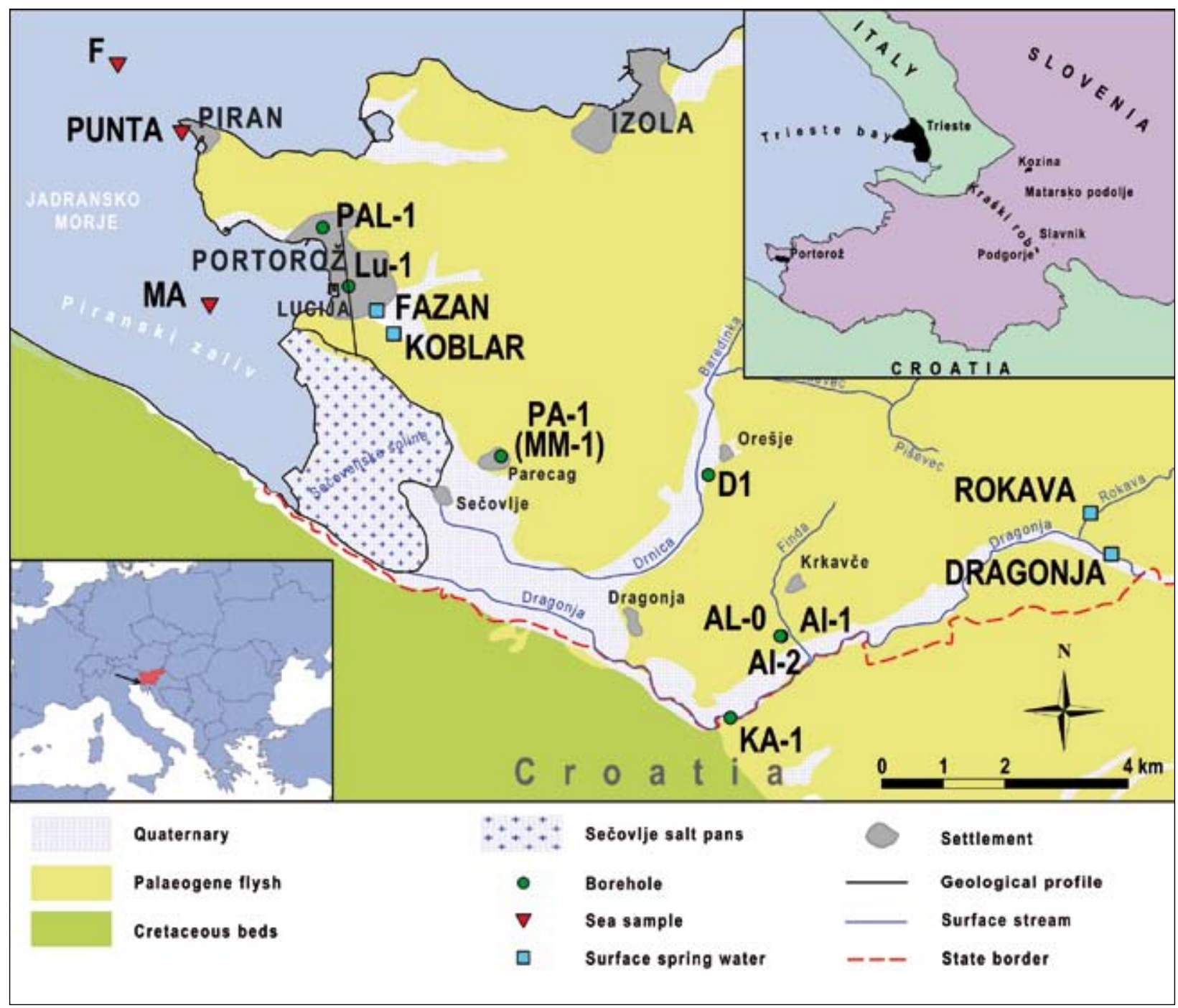

Fig. 1: Geographic position of borehole Lu-1 and other sampling points from the study (geology modified after Pleničar et al.1973).

the wider Portorož environs (Fig. 1). Details about the sampling methodology are given below. Sampling was performed in borehole D-1 near Orešje on the left bank of Drnica creek near the village of Dragonja. The borehole was drilled to a depth of $450 \mathrm{~m}$ where in the interval between $254 \mathrm{~m}$ and $450 \mathrm{~m}$ limestone is present. Samples were also taken from boreholes Al-0, Al-1, and Al-2, which are positioned southwest of Krkavče. The boreholes are drilled to depths of $140 \mathrm{~m}, 183 \mathrm{~m}$, and $240 \mathrm{~m}$ respectively and are positioned close to each other. Boreholes Al-0 and Al-1 were completed in flysch rocks; in borehole Al-2 limestone starts at the depth of $158 \mathrm{~m}$. On the foothill below the village of Parecag near the abandoned inn on the southern side of the Portorož-Sečovlje road, sample PA-1 was taken from borehole MM-1; this borehole was completed at the depth of $380 \mathrm{~m}$ and flysch ends at $210 \mathrm{~m}$. In the area of Krkavče, samples were col- lected from borehole KA-1. In this borehole flysch ends at $36 \mathrm{~m}$ and limestone is present until the final depth of $404 \mathrm{~m}$. For the interpretation, sample PAL-1 from borehole HV-1 near the Palace hotel in Portorož was available. The borehole was drilled to a depth of $705 \mathrm{~m}$ in similar lithological conditions to borehole Lu-1; however fissures are very seldom. Samples were also taken from springs in the vicinity (Fazan, Koblar) and from surface waters (river Dragonja and creek Rokava). 


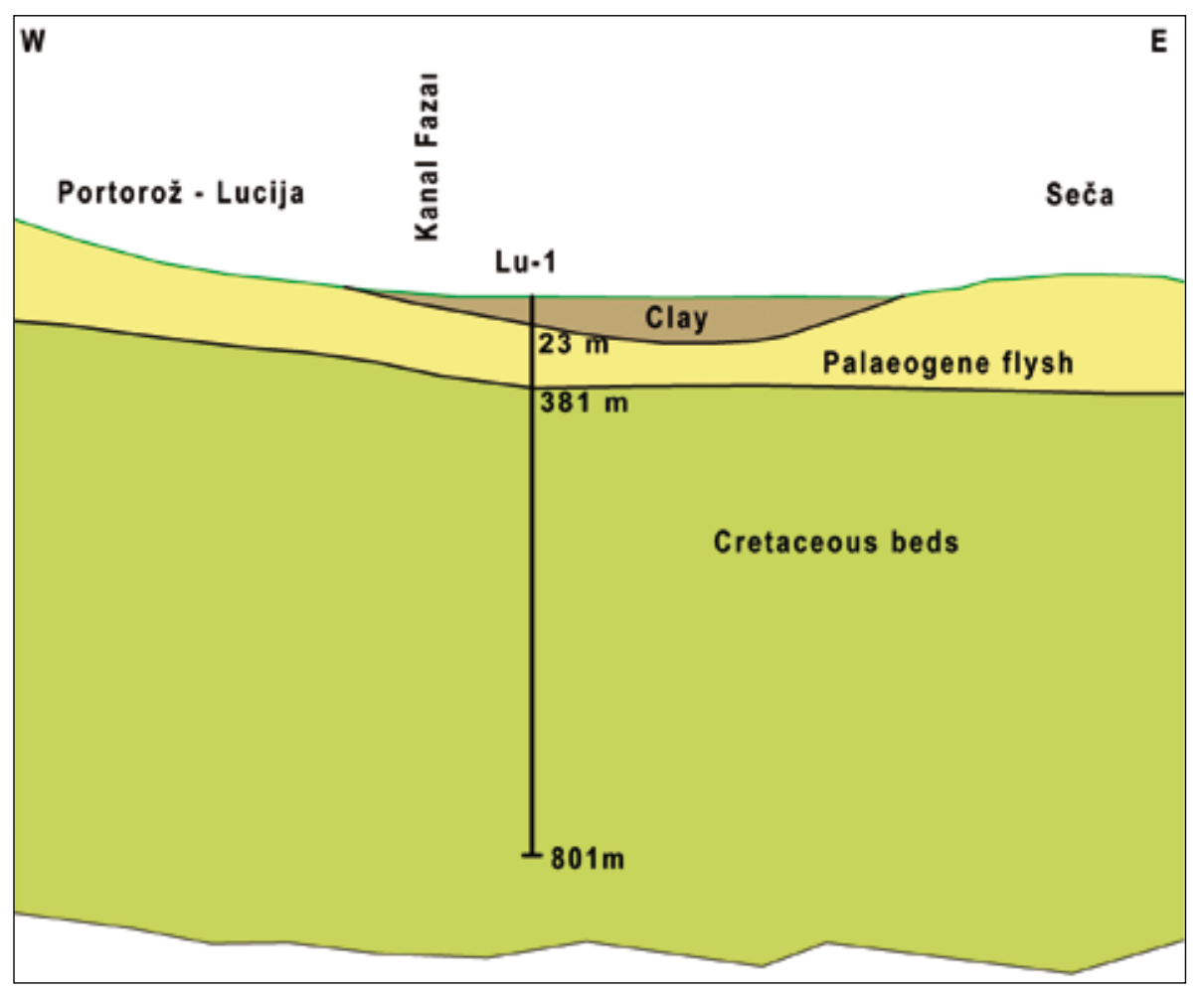

Fig. 2: Schematic geological profile with borehole $\mathrm{Lu}-1$ position.

\section{METHODS}

\section{SAMPLING AND CHEMICAL ANALYSES}

Samples of groundwater were collected during the course of drilling of borehole Lu-1 (marked as P1 to P10). They were taken at the mouth of the tubing at the place where water overflowed. The sampling campaign was part of logging procedures intended to identify any changes in the borehole column. Samples taken during drilling operations were stored in plastic PVC bottles. In the lab they were filtered through a membrane filter with a $0.45 \mu \mathrm{m}$ pore diameter. The only exceptions are samples P9 and P10 (Tab. 1), which were filtered and fixed in the field. These samples were acidified to $\mathrm{pH}<2$ for $\mathrm{Fe}^{2+}$ and $\mathrm{Fe}^{3+}$ determination.

Groundwater and surface water samples that were used for the comparative analyses of groundwater from borehole Lu-1 were taken during investigations performed in 1993 and 1994. The results are mainly obtained from drilling reports from the Archive of Geological Survey of Slovenia. Collected samples were not treated in the field.

The majority of samples were analysed in the Laboratory for Water Chemistry, Biology, and Technology at the Chemistry Institute of Ljubljana, Slovenia. The only exceptions are analyses of sample KA 1/22 from 12
February 1993, which were performed in Public Health Survey of Novo mesto, Slovenia. The analyses performed are presented in Tabs. 1 to 4 . During the pumping test in borehole Lu-1 between 4 and 5 May 1994, samples were also collected for salinity determination at the marine biology station at Piran.

Seawater samples from Piranski zaliv were taken at two sampling points usually used by the Marine Biology Station at Piran. They were collected from the sea bottom and from the surface (MA samples: longitude 13.57, latitude 45.50333; F samples: longitude 13.55, latitude 45.53833). Samples were stored in the refrigerator at $-20^{\circ} \mathrm{C}$. They were analysed by suppressor ion chromatography at the Department of Chemistry and Chemical Technology, Faculty for Natural Sciences and Technology, University of Ljubljana.

The results of stable $\delta^{18} \mathrm{O}$ isotope determination are expressed in standard delta notation $(\delta)$ as per mil (\%o) deviation from the standard as:

$$
\delta^{18} O(\%)=\left(\frac{\mathrm{R}_{\text {sample }}}{\mathrm{R}_{\text {std }}}-1\right) \times 1000
$$

where $\mathrm{R}_{\text {sample }}$ and $\mathrm{R}_{\text {std }}$ are ratios of the stable isotopes of ${ }^{18} \mathrm{O} /{ }^{16} \mathrm{O}$ of sample and standard (V SMOW), respectively. 
Tab. 1: Chemical analyses from borehole Lu-1 obtained during drilling.

\begin{tabular}{|c|c|c|c|c|c|c|c|c|c|c|c|}
\hline Sample & & P1 & $P 2$ & P3 & P4 & P5 & P6 & P7 & P8 & P9 & P10 \\
\hline Depth & $\mathrm{m}$ & 43.0 & 65.0 & 91.0 & 113.0 & 190.0 & 500.0 & 611.5 & 704.0 & 800.0 & 800.0 \\
\hline Date & & 09.03 .94 & 11.03 .94 & 13.03 .94 & 14.03 .94 & 16.03 .94 & 12.04 .94 & 19.04 .94 & 25.04 .94 & 04.05 .94 & 05.05.94 \\
\hline $\mathrm{K}^{+}$ & $\mathrm{mg} / \mathrm{l}$ & 4.0 & 3.3 & 4.5 & 5.5 & 7.3 & 140 & 125 & 130 & 130 & 135 \\
\hline $\mathrm{Na}^{+}$ & $\mathrm{mg} / \mathrm{l}$ & 290 & 295 & 647 & 613 & 524 & 3700 & 3500 & 3600 & 3500 & 3600 \\
\hline $\mathrm{NH}_{4}-\mathrm{N}$ & $\mathrm{mg} / \mathrm{l}$ & $<0.04$ & - & - & - & 0.61 & 2.2 & 2.0 & 1.9 & 1.6 & 1.6 \\
\hline $\mathrm{Ca}^{2+}$ & $\mathrm{mg} / \mathrm{l}$ & 405 & 505 & 231 & 251 & 327 & 428 & 434 & 416 & 435 & 417 \\
\hline $\mathrm{Mg}^{2+}$ & $\mathrm{mg} / \mathrm{l}$ & 45.3 & 59.8 & 38.7 & 41.1 & 48.4 & 257 & 258 & 258 & 258 & 258 \\
\hline $\mathrm{Cl}^{-}$ & $\mathrm{mg} / \mathrm{l}$ & 1210 & 1390 & 1315 & 1365 & 1365 & 6700 & 6700 & 6500 & 6700 & 6700 \\
\hline $\mathrm{HCO}_{3}^{-}$ & $\mathrm{mg} / \mathrm{l}$ & 300 & 282 & 343 & 325 & 309 & 306 & 232 & 235 & 300 & 262 \\
\hline $\mathrm{NO}_{2}^{-} \mathrm{N}$ & $\mathrm{mg} / \mathrm{l}$ & 0.002 & 0.002 & 0.001 & 0.001 & 0.002 & $<0.002$ & $<0.002$ & $<0.002$ & $<0.002$ & $<0.002$ \\
\hline $\mathrm{NO}_{3}^{-}-\mathrm{N}$ & $\mathrm{mg} / \mathrm{l}$ & $<0.1$ & $<0.1$ & $<0.1$ & $<0.1$ & $<0.1$ & $<0.1$ & $<0.1$ & $<0.1$ & $<0.1$ & $<0.1$ \\
\hline $\mathrm{SO}_{4}^{2-}$ & $\mathrm{mg} / \mathrm{l}$ & 45.9 & 34.8 & 16.9 & 20.4 & 29.6 & 800 & 854 & 809 & 800 & 789 \\
\hline $\mathrm{SiO}_{2}$ & $\mathrm{mg} / \mathrm{l}$ & 15.2 & 13.8 & 12.6 & 12.6 & 13.1 & 17.4 & - & - & 16.2 & 15.6 \\
\hline $\mathrm{Fe}_{\text {tot }}$ & $\mathrm{mg} / \mathrm{l}$ & $<0.01$ & - & - & - & - & 5.2 & 0.13 & $<0.01$ & 0.2 & 10.4 \\
\hline $\mathrm{Fe}^{2+}$ & $\mathrm{mg} / \mathrm{l}$ & & - & - & - & - & - & - & - & 0.2 & 8.3 \\
\hline $\mathrm{Mn}_{\text {tot }}$ & $\mathrm{mg} / \mathrm{l}$ & $<0.01$ & - & - & - & - & $<0.01$ & - & - & - & - \\
\hline $\mathrm{pH}$ & & 7.0 & 7.0 & 7.3 & 7.3 & 7.2 & 7.7 & 7.3 & 7.6 & 7.4 & 8.0 \\
\hline Dry $105^{\circ} \mathrm{C}$ & $\mathrm{mg} / \mathrm{l}$ & 2380 & 2625 & 2695 & 2550 & 2715 & 12100 & - & - & - & - \\
\hline $\mathrm{KMnO}_{4}$ & $\mathrm{mg} / \mathrm{l}$ & 6.0 & - & - & - & - & - & - & - & 136 & 101 \\
\hline $\mathrm{Sr}^{2+}$ & $\mathrm{mg} / \mathrm{l}$ & - & - & - & - & - & - & - & - & 18 & 18 \\
\hline $\mathrm{Br}^{-}$ & $\mathrm{mg} / \mathrm{l}$ & - & - & - & - & - & - & - & - & 28.6 & 29.4 \\
\hline $\mathrm{H}_{2} \mathrm{~S}$ & $\mathrm{mg} / \mathrm{l}$ & - & - & - & - & - & - & - & - & 33 & 19 \\
\hline $\mathrm{S}_{2}^{-}$ & $\mathrm{mg} / \mathrm{l}$ & - & - & - & - & - & - & - & - & 15 & 0.6 \\
\hline TC & $\mathrm{mg} / \mathrm{l}$ & - & - & - & - & - & - & - & - & 58.6 & 51.7 \\
\hline IC & $\mathrm{mg} / \mathrm{l}$ & - & - & - & - & - & - & - & - & 55.6 & 49.3 \\
\hline TOC & $\mathrm{mg} / \mathrm{l}$ & - & - & - & - & - & - & - & - & 3.0 & 2.4 \\
\hline$\delta^{18} \mathrm{O}$ & $\%$ & - & -6.31 & -7.21 & -7.15 & - & -5.79 & -5.73 & - & -5.70 & -5.73 \\
\hline
\end{tabular}

Positive $\delta^{18} \mathrm{O}$ values show relative enrichment of the material in the heavy isotope with respect to the standard and negative $\delta^{18} \mathrm{O}$ values indicate a lighter composition than the standard. The $\delta^{18} \mathrm{O}$ analyses were performed on a dual inlet VARIAN MAT 250 stable isotope mass spectrometer.

Gas $\left(\mathrm{CH}_{4}, \mathrm{~N}_{2}, \mathrm{Ar}, \mathrm{CO}_{2}, \mathrm{C}_{2} \mathrm{H}_{6}\right.$, and $\left.\mathrm{C}_{3} \mathrm{H}_{8}\right)$ analyses were performed with gas chromatography where volumetric parts of gases were determined. Stable isotope and gas analyses were performed at Jožef Stefan Institute.

\section{INTERPRETATION METHODOLOGY}

For the interpretation of chemical and isotope analyses the following methods were used: ion pattern analyses, hydrogeochemical facies, comparative analyses between dissolved species, grapho-analytical methods, mixing models, and geochemical modelling.

Ion pattern analyses define samples according to the concentration of dominant dissolved species. For the hydrogeochemical facies determination, definitions according to Back (1961) based on the Piper diagram (Piper 1944) were followed (Domenico \& Schwartz 1990). 
The interpretation of water chemical analyses was based on molar ratios between dissolved species. This is a classical hydrogeochemical method based on the analogy and comparison of empirical values obtained in comparable aquifers. Usually molar ratios are used for the groundwater source determination (Schoeller 1962). We used mainly ratios based on $\mathrm{Cl}^{-}$because absorption of this species on the mineral surfaces from the aquifers is minor and can be used as a conservative tracer (Hem 1985). Absorption of $\mathrm{Cl}^{-}$is possible only in aquifers with very old groundwater; however this is not the case in the carbonate coastal aquifer of Lucija-Portorož. Further molar ratios of $\mathrm{Ca}^{2+} / \mathrm{Cl}^{-}$and $\mathrm{SO}_{4}{ }^{2-} / \mathrm{Cl}^{-}$and $\mathrm{Cl}^{-} / \mathrm{HCO}_{3}{ }^{-}$indicate mixing of seawater and groundwater. Ratios where $\mathrm{SO}_{4}^{2-}$ and $\mathrm{HCO}_{3}^{-}$are included indicate redox conditions in the aquifer. Differentiation between waters from dolomite and limestone can be done with the help of the $\mathrm{Ca}^{2+} / \mathrm{Mg}^{2+}$ ratio. Parameter IEB1 is defined as the molar quotient $\left(\mathrm{Cl}^{-}-\mathrm{Na}^{+}+\mathrm{K}^{+}\right) / \mathrm{Cl}^{-}$, which shows whether part of $\mathrm{Na}^{+}$and $\mathrm{K}^{+}$has been replaced with $\mathrm{Ca}^{2+}$ and $\mathrm{Mg}^{2+}$ (Schoeller 1962).

In the grapho-analytical methods, Piper (1944) diagram and indication diagrams based on D'Amore et al. (1983) were used. A Piper diagram is represented as a projection of cation and anion ternary diagrams into rhombic space. Diagrams according to D'Amore et al. (1983) are based on the interpretation of the Piper diagram. In these diagrams indication parameters denoted by the letters $A$ to $F$ are used. Parameters are presented as line diagrams where the whole diagram and not just one particular parameter is used for the chemical determination of the sample. Parameters are defined according to the following equations:

$$
\begin{aligned}
& A=\left(\frac{\left[\mathrm{HCO}_{3}^{-}\right]-\left[\mathrm{SO}_{4}^{2-}\right]}{\sum(-)}\right) 100 \\
& B=\left(\frac{\left[\mathrm{SO}_{4}^{2-}\right]}{\sum(-)}-\frac{\left[\mathrm{Na}^{+}\right]}{\sum(+)}\right) 100 \\
& C=\left(\frac{\left[\mathrm{Na}^{+}\right]}{\sum(+)}-\frac{\left[\mathrm{Cl}^{-}\right]}{\sum(-)}\right) 100 \\
& D=\left(\frac{\left[\mathrm{Na}^{+}\right]-\left[\mathrm{Mg}^{2+}\right]}{\sum(+)}\right) 100 \\
& E=\left(\frac{\left[\mathrm{Ca}^{2+}\right]+\left[\mathrm{Mg}^{2+}\right]}{\sum(+)}-\frac{\left[\mathrm{HCO}_{3}^{-}\right]}{\sum(-)}\right) 100
\end{aligned}
$$

$$
F=\left(\frac{\left[\mathrm{Ca}^{2+}\right]-\left[\mathrm{Na}^{+}\right]-\left[\mathrm{K}^{+}\right]}{\sum(+)}\right) 100
$$

Parameters define the ratio between dissolved species where square brackets represent concentrations in meq/l. Sum $\Sigma$ represents the sum of the anion (-) and cation $(+)$ concentrations. Parameter $A$ discerns water flowing through carbonate aquifers from water that flow through rocks enriched with gypsiferous evaporites. Parameter $B$ distinguishes waters related with sulphates (e.g. gypsum) from waters that originate from marls and clay rocks rich with $\mathrm{Na}^{+}$. Parameter $C$ distinguishes waters from flysch rocks and waters from evaporitic rocks. Parameter $D$ defines waters from dolomitic rocks. Parameter $E$ distinguishes waters that originate from carbonate rock from waters rich in sulphate. Parameter $F$ shows enriched $\mathrm{K}^{+}$concentrations (D’Amore et al. 1983).

Due to the very low yield until the depth of $190 \mathrm{~m}$ the groundwater temperature in borehole $\mathrm{Lu}-1$ was interpreted as $14^{\circ} \mathrm{C}$, representing the annual average air temperature in the area. From this depth onward the temperature of flowing water was considered to be $23^{\circ} \mathrm{C}$ as it was measured at the casing mouth.

\section{MIXING MODEL}

$\delta^{18} \mathrm{O}$ and $\mathrm{Cl}^{-}$are considered to be conservative tracers. They can be used in the two component end member mixing models for the interpretation of seawater-groundwater mixing. The model is based on the equations:

where

$$
\begin{aligned}
& x_{1}+x_{2}=1 \\
& x_{1} c_{1}+x_{2} c_{2}=c_{3}
\end{aligned}
$$

$\mathrm{x}_{1}$ is the volumetric proportion in the first component,

$\mathrm{x}_{2}$ is the volumetric proportion in the second component,

$c_{1}$ is the concentration of the conservative tracer in the first component,

$c_{2}$ is the concentration of the conservative tracer in the second component, and

$\mathrm{c}_{3}$ is the concentration in the sample mixture (borehole Lu-1).

\section{THERMODYNAMICAL CALCULATIONS}

Thermodynamical calculations were performed with the help of the geochemical code WATEQ4F (Plummer et al. 1976). Saturation indexes ( $\mathrm{SI}_{\text {mineral }}$ ) of minerals available in the aquifer, partial pressures of $\mathrm{CO}_{2}$ defined as $\mathrm{pCO}_{2}$, and redox potential Eh were calculated. 


\section{RESULTS}

Results of chemical analyses are given in Tabs. 1-4. The results of grapho analytical and thermodynamic calculations are given in Tabs. 5-8 and Figs. 2 and 4 .

Comparison between cation and anion sums shows that relative error in chemical analyses is in the range between $1 \%$ and $5 \%$. Higher concentrations of $\mathrm{Cl}^{-}$presented in the majority of samples, causing problems in determination of concentrations of other dissolved species. Therefore some determinations are subject to higher analytical errors than usual. During the interpretation all efforts were taken to obtain reliable data from the archive records.

During the pumping test in borehole $\mathrm{Lu}-1$, the salinity of water flowing out from the borehole was determined as $13.71 \%$. Together with stable isotope results of $\delta^{18} \mathrm{O}$ from Lu-1, which are given in Tab. 1, samples for $\delta^{18} \mathrm{O}$ were also taken at the depth of $278 \mathrm{~m}$ where the value of $\delta^{18} \mathrm{O}$ of -5.75\% was obtained and at the depth of $405 \mathrm{~m}$ where the value of $\delta^{18} \mathrm{O}$ of $-5.73 \%$ was obtained.
In the seawater near Punta in Piran the $\delta^{18} \mathrm{O}$ value of $+0.42 \%$ was obtained. In the spring at Fazan the $\delta^{18} \mathrm{O}$ value was $-6.44 \%$ and in the spring behind the petrol station near the abandoned Koblar restaurant the $\delta^{18} \mathrm{O}$ value was $-6.37 \%$. Both samples were taken on 5 May 1994 .

In the borehole D-1 near Orešje (Fig. 1) more samples were taken over a longer period. In December 1981 the $\delta^{18} \mathrm{O}$ value was $-8.19 \%$, on 16 July 1982 the $\delta^{18} \mathrm{O}$ value was $-8.57 \%$, and on 19 April 1993 the $\delta^{18} \mathrm{O}$ value was $-8.69 \%$ (Marinko 1994).

More detailed analyses were performed on the sample taken from borehole Al-0 (Fig. 1) on 7 July 1993. The $\mathrm{pH}$ of the water was 7.13 and the isotopic compositions of oxygen and deuterium were $-6.19 \%$ and $-41.5 \%$ respectively. The $\delta^{13} \mathrm{C}$ value in DIC was $-1.96 \%$. The gas emanating from the borehole has the following volumetric composition: $97.58 \% \mathrm{CH}_{4}, 1.83 \% \mathrm{~N}_{2}, 0.02 \% \mathrm{Ar}$, $0.13 \% \mathrm{CO}_{2}, 0.34 \% \mathrm{C}_{2} \mathrm{H}_{6}$ and $0.09 \% \mathrm{C}_{3} \mathrm{H}_{8}$. The $\delta^{13} \mathrm{C}$ isotopic composition of the methane was $-71.2 \%$.

\section{DISCUSSION AND INTERPRETATION}

\section{CONCEPTUAL MODEL}

Borehole Lu-1 was drilled next to the sea. It was drilled in the upper part through the Palaeocene and Eocene flysch and in the lower part through the Palaeogene and Cretaceous limestone. According to the relatively high transmissivity of $\mathrm{T}=6.3 \times 10^{-4} \mathrm{~m}^{2} / \mathrm{s}$ determined during the pumping test it can be concluded that below the flysch cover of low permeability, a high yield and permeable confined carbonate aquifer exists (Marinko 1994). Based on the pumping test we can conclude that the aquifer is very permeable and that existent fissures and cracks conduct water efficiently; however, based on drilling results and later logging the existence of caverns inside the limestone was not proved. Due to the near vicinity of sea and limestones' high organic content, the hydrogeochemistry of the groundwater is complex and not typical for Cretaceous and Palaeogene limestone aquifers from the Dinaric carbonate platform. At the same time the results for borehole Lu-1 indicate that similar hydrogeochemical conditions exist in the whole coastal aquifer of the Slovene part of Istra; the results of chemical analyses from submarine springs next to Izola (Žumer 2004, 2008; Faganeli et al. 2005) show some resemblance.

The hydrogeochemical conditions of aquifer systems that were drilled through by borehole Lu-1 were interpreted using the conceptual model shown in Fig. 4. This conceptual model is constructed based on a master log of the borehole (Marinko 1994) and on the geological and structural interpretations of the wider area (Placer 1981, 2005, 2007). The mixing of seawater from Piranski zaliv and groundwater originating from the hinterland karstified aquifer appeared in the coastal carbonate aquifer. Limestone's high organic matter content induces a chain of redox reactions.

\section{HYDROGEOCHEMICAL FACIES ANALYSES}

Comparison of ion pattern and hydrogeochemical facies shows that water in the aquifer captured with borehole Lu1 is chemically stratified (Tabs. 5 and 6). Until the depth of $65 \mathrm{~m}, \mathrm{Ca}^{2+}-\mathrm{Na}^{+}-\mathrm{Cl}^{-}-\mathrm{SO}_{4}^{2-}-\mathrm{HCO}_{3}^{-}$facies is present, followed by $\mathrm{Na}^{+}-\mathrm{Ca}^{2+}-\mathrm{Cl}^{-}-\mathrm{SO}_{4}{ }^{2-}-\mathrm{HCO}_{3}{ }^{-}$until the depth of $113 \mathrm{~m}$, and from the depth of $500 \mathrm{~m}$ until the end of the borehole $\mathrm{Na}^{+}-\mathrm{Ca}^{2+}-\mathrm{Cl}^{-}-\mathrm{SO}_{4}{ }^{2-}$ facies is present. The latter facies is also present in boreholes HV-1/94 (sample PAL-1) and Al-0 and in seawater of Punta Piran, showing that hydrogeochemical stratification of the aquifer is present in the whole coastal aquifer around Portorož. Facies stratification is common in coastal aquifers in intergranular aquifers (Appelo \& Postma 1993) as well as in carbonate coastal aquifers where local stratig- 


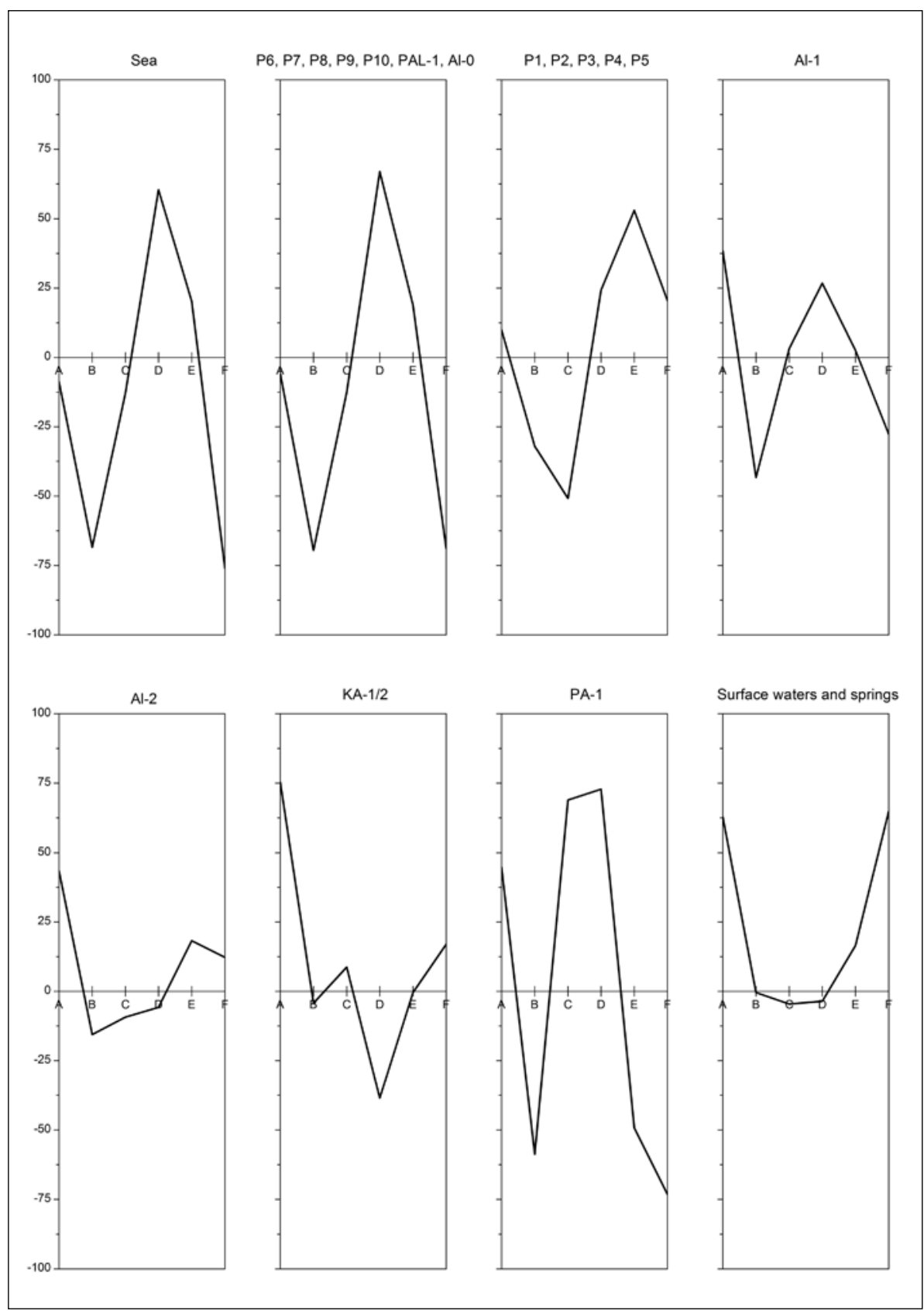

Fig. 3: Indicator diagrams according to D’Amore et al. (1983).

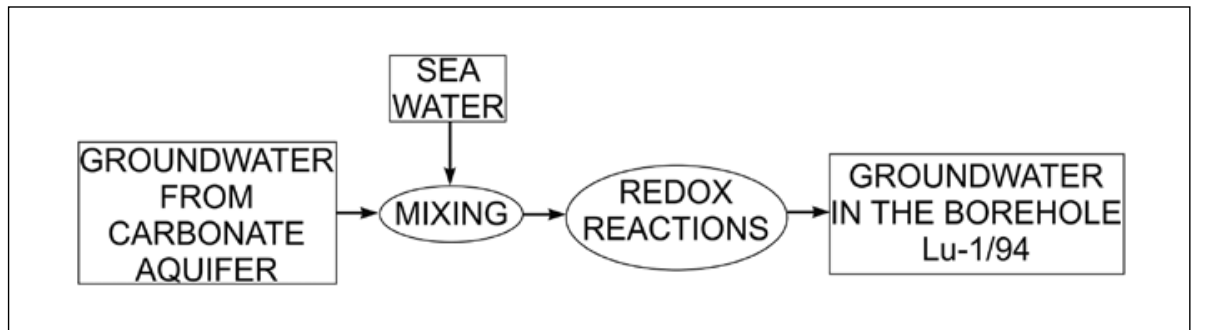

Fig. 4: Hydrogeochemical conceptual model of the coastal carbonate aquifer from Lucija Portorož (borehole Lu-1). raphy does not consist only of carbonate rocks (Wicks \& Herman 1996).

Molar ratios of the samples from borehole Lu-1 represent the autonomous group, in which resemble in some instances the samples from the Palace borehole PAL-1 and borehole Al-0 (Fig. 1 and Tab. 7). Three distinctive groups of molar $\mathrm{SO}_{4}{ }^{2-} / \mathrm{Cl}^{-}$ratios can be observed. The ratio from the Punta in Piran is 0.05 . Values for samples from deeper than $500 \mathrm{~m}$ from borehole Lu-1 are somewhat lower, between 0.043 and 0.046 . In sample PAL-1 the actual ratio is 0.06 , higher than samples from Lu- 1 . Relatively low values below 0.01 can be found in samples from P2 to P5 and Al-0. In all other samples the ratio is much higher, showing the predominant influence of groundwater from the continent. Three groups can also be observed in the molar $\mathrm{Ca}^{2+} / \mathrm{Cl}^{-}$ratio. Again samples P6 to P10, Al-0, and PAL-1 represent the independent group. Slightly higher ratios can be found in samples P1 to P5. Samples Al-1 and AL-2 can be included in this group. In all other samples, higher values are observed.

A similar grouping can be expected in the molar $\mathrm{Cl}^{-} / \mathrm{HCO}_{3}{ }^{-}$ratio; however this is not the case. Samples Al-1 and Al-2 cannot be included in the group of $\mathrm{P} 1$ to P5. The molar $\mathrm{Ca}^{2+} / \mathrm{Mg}^{2+}$ ratio has great discrimination potential. Samples P1 to $\mathrm{P} 5$ represent independent groups with values between 3.6 and 5.4. Samples P6 to P10 have very comparable 


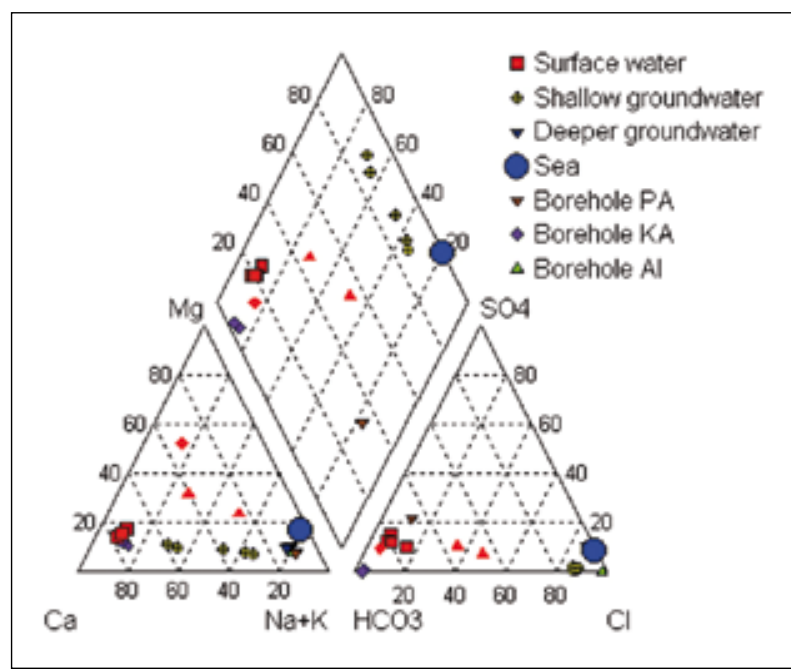

Fig. 5: Piper diagram. values near to 1 . Similar values between 0.6 and 1.3 can be found in samples Al-0, Al-1, Al-2, KA-1/1, PA-1, and PAL-1, which originate from flysch rocks. All other samples show a predominance of $\mathrm{Ca}^{2+}$.

Indicator diagrams by D'Amore et al. (1983) show the very distinctive origin of sampled waters (Fig. 3). Diagrams of samples P6, P7, P8, P9, P10, PAL-1, and Al-0 have nearly identical shapes to the diagram for the sea near Punta in Piran. Very similar shapes can be seen for samples P1 to P5; however, the range of parameters is smaller, especially for parameter $B$, which represents the influence of $\mathrm{Na}^{+}$, and parameter $\mathrm{E}$, which discerns waters rich in sulphates. All these patterns show that the concentrations of $\mathrm{Na}^{+}$and $\mathrm{SO}_{4}^{2-}$ are lower compared to the first group. Other diagrams are completely different. A diagram of sample Al 1 shows high similarity with diagrams from the second group. Surface waters and waters

Tab. 2: Chemical analyses from the borehole groundwater samples in the wider environs of Lucija Portorož.

\begin{tabular}{|c|c|c|c|c|c|c|c|c|c|}
\hline Sample & & Al-0 & Al-1 & Al-2 & $K A-1 / 1$ & $K A 1 / 21$ & KA 1/22 & $P A-1$ & PAL-1 \\
\hline Date & & 03.07 .93 & 31.08 .93 & 22.05 .94 & 20.01 .93 & 12.02 .93 & 15.02 .93 & 07.07 .93 & 03.06.94 \\
\hline Depth & $\mathrm{m}$ & - & - & - & $100-400$ & - & - & - & - \\
\hline $\mathrm{K}^{+}$ & $\mathrm{mg} / \mathrm{l}$ & 40 & 7.5 & 5.4 & 3.7 & 2.0 & 1.1 & 5.0 & 108 \\
\hline $\mathrm{Na}^{+}$ & $\mathrm{mg} / \mathrm{l}$ & 3450 & 150 & 50 & 22.0 & 29 & 20.6 & 115 & 2640 \\
\hline $\mathrm{NH}_{4}-\mathrm{N}$ & $\mathrm{mg} / \mathrm{l}$ & $<0.04$ & 1.1 & & 0.06 & 0.87 & 2.3 & 3.3 & 0.9 \\
\hline $\mathrm{Ca}^{2+}$ & $\mathrm{mg} / \mathrm{l}$ & 405 & 62.8 & 66.7 & 44.3 & 136 & 123 & 11.8 & 369 \\
\hline $\mathrm{Mg}^{2+}$ & $\mathrm{mg} / \mathrm{l}$ & 185 & 37.4 & 32.3 & 43.7 & 12 & 12.4 & 5.9 & 179 \\
\hline $\mathrm{Cl}^{-}$ & $\mathrm{mg} / \mathrm{l}$ & 6500 & 215 & 110 & 12.8 & 9.9 & 8.0 & 30 & 4750 \\
\hline $\mathrm{HCO}_{3}^{-}$ & $\mathrm{mg} / \mathrm{l}$ & 228 & 357 & 287 & 355 & 509 & 508 & 295 & 233 \\
\hline $\mathrm{NO}_{2}^{-}-\mathrm{N}$ & $\mathrm{mg} / \mathrm{l}$ & $<0.002$ & $<0.002$ & - & $<0.002$ & $<0.01$ & $<0.002$ & $<0.002$ & - \\
\hline $\mathrm{NO}_{3}^{-}-\mathrm{N}$ & $\mathrm{mg} / \mathrm{l}$ & 1.1 & $<0.4$ & - & $<0.01$ & $<0.5$ & $<0.01$ & $<0.4$ & - \\
\hline $\mathrm{SO}_{4}^{2-}$ & $\mathrm{mg} / \mathrm{l}$ & 3.7 & 44.4 & 44.2 & 31.7 & 3.6 & 1.6 & 76.1 & 800 \\
\hline $\mathrm{SiO}_{2}$ & $\mathrm{mg} / \mathrm{l}$ & - & - & 24.0 & - & 13.5 & - & 0.6 & 24.4 \\
\hline $\mathrm{Fe}_{\text {tot }}$ & $\mathrm{mg} / \mathrm{l}$ & 0.8 & 0.79 & - & 0.02 & 5.3 & 4.9 & 17.3 & - \\
\hline $\mathrm{Mn}_{\text {tot }}$ & $\mathrm{mg} / \mathrm{l}$ & $<0.01$ & $<0.01$ & - & $<0.01$ & 0.28 & 0.27 & $<0.01$ & - \\
\hline $\mathrm{pH}$ & & 6.9 & 8.4 & - & 8.1 & 7.0 & 7.2 & 8.9 & 7.6 \\
\hline Dry $105^{\circ} \mathrm{C}$ & $\mathrm{mg} / \mathrm{l}$ & 12990 & 780 & - & 367 & - & 456 & 397 & - \\
\hline Dry $180^{\circ} \mathrm{C}$ & $\mathrm{mg} / \mathrm{l}$ & 12300 & - & - & - & 433 & - & - & - \\
\hline $\mathrm{KMnO}_{4}$ & $\mathrm{mg} / \mathrm{l}$ & 180 & 120 & - & 12.0 & 2.3 & 10.4 & 9.0 & - \\
\hline $\mathrm{Sr}^{2+}$ & $\mathrm{mg} / \mathrm{l}$ & - & - & 5.7 & - & - & - & - & 11 \\
\hline $\mathrm{Br}^{-}$ & $\mathrm{mg} / \mathrm{l}$ & - & - & 0.2 & - & $<0.1$ & - & - & 13.5 \\
\hline $\mathrm{H}_{2} \mathrm{~S}$ & $\mathrm{mg} / \mathrm{l}$ & - & 15.6 & - & - & - & - & - & - \\
\hline $\mathrm{S}_{2}^{-}$ & $\mathrm{mg} / \mathrm{l}$ & - & - & - & 7.3 & - & $<0.1$ & - & - \\
\hline TC & $\mathrm{mg} / \mathrm{l}$ & - & - & - & - & - & - & - & 46.5 \\
\hline IC & $\mathrm{mg} / \mathrm{l}$ & - & - & - & - & - & - & - & 45.2 \\
\hline TOC & $\mathrm{mg} / \mathrm{l}$ & - & - & - & - & - & - & - & 1.3 \\
\hline
\end{tabular}




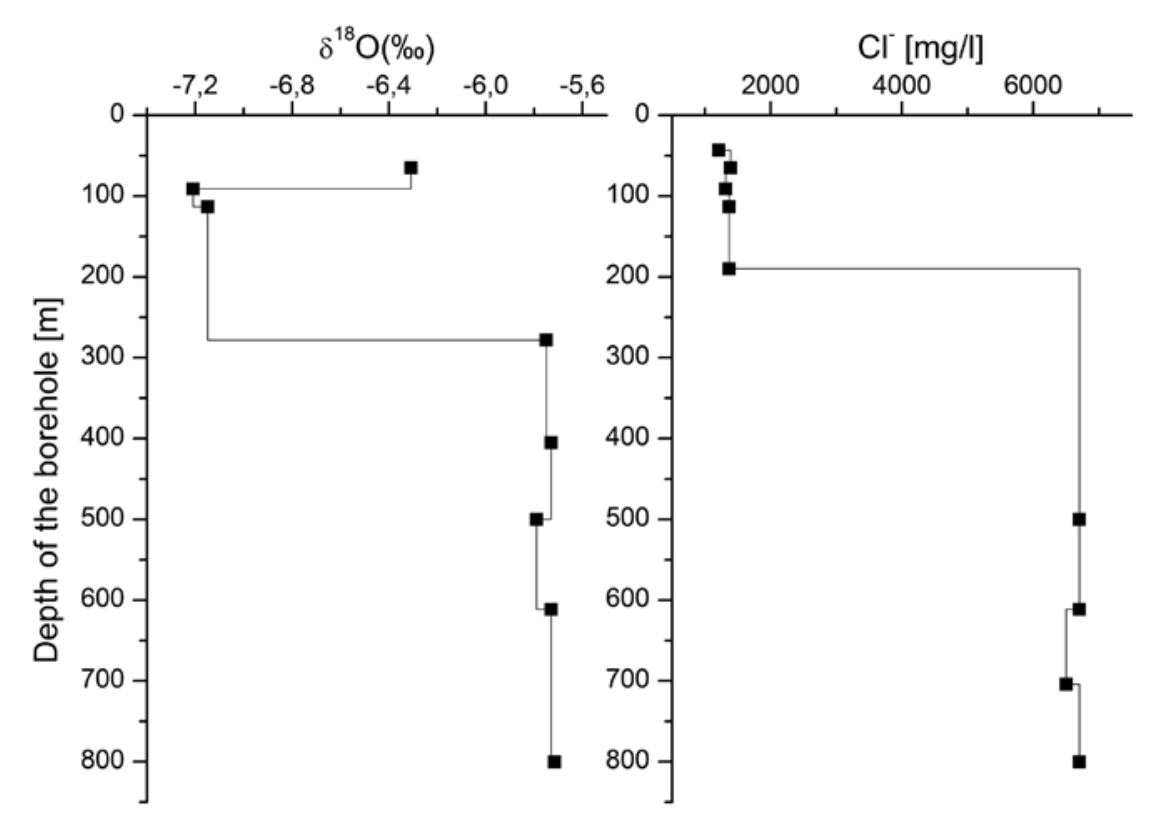

Fig. 6: Vertical distribution of $\mathrm{Cl}$ and $\delta^{18} \mathrm{O}$ in groundwater outflowing during driling from borehole $\mathrm{Lu}-1$.

from the springs show patterns that are representative for aquifers under the predominant influence of carbonates with low $\mathrm{Mg}^{2+}$ concentrations. Similar to the latter group is the diagram of samples KA-1/21 and KA-1/22, with a

Tab. 3: Chemical analyses from the spring water, surface waters, and sea of Piranski zaliv.

\begin{tabular}{|l|c|c|c|c|c|c|c|}
\hline Watercourse & & Fazan & Koblar & Rokava & Dragonja 1 & Dragonja 2 & Punta-sea \\
\hline Date & & 05.05 .94 & 05.05 .94 & 03.06 .94 & 20.01 .94 & 03.06 .94 & 13.04 .94 \\
\hline $\mathrm{K}^{+}$ & $\mathrm{mg} / \mathrm{l}$ & 1.5 & 1.5 & 2 & 0.7 & 2 & 480 \\
\hline $\mathrm{Na}^{+}$ & $\mathrm{mg} / \mathrm{l}$ & 13 & 9 & 11 & 7.7 & 11 & 11800 \\
\hline $\mathrm{NH}_{4}{ }^{-\mathrm{N}}$ & $\mathrm{mg} / \mathrm{l}$ & $<0.04$ & $<0.04$ & $<0.04$ & $<0.04$ & $<0.04$ & $<0.1$ \\
\hline $\mathrm{Ca}^{2+}$ & $\mathrm{mg} / \mathrm{l}$ & 129 & 130 & 80.0 & 86.2 & 71.4 & 450 \\
\hline $\mathrm{Mg}^{2+}$ & $\mathrm{mg} / \mathrm{l}$ & 20.2 & 10.8 & 10.2 & 9.6 & 10.8 & 1380 \\
\hline $\mathrm{Cl}^{-}$ & $\mathrm{mg} / \mathrm{l}$ & 46 & 21 & 15.2 & 9.7 & 10.9 & 21300 \\
\hline $\mathrm{HCO}_{3}^{-}$ & $\mathrm{mg} / \mathrm{l}$ & 402 & 396 & 249 & 265 & 226 & 160 \\
\hline $\mathrm{NO}_{2}^{-}-\mathrm{N}$ & $\mathrm{mg} / \mathrm{l}$ & - & - & $<0.009$ & $<0.002$ & 0.27 & 0.003 \\
\hline $\mathrm{NO}_{3}^{-}-\mathrm{N}$ & $\mathrm{mg} / \mathrm{l}$ & 7.6 & 7.4 & 0.21 & 1.4 & 0.02 & $<0.1$ \\
\hline $\mathrm{SO}_{4}^{2-}$ & $\mathrm{mg} / \mathrm{l}$ & - & - & 30.4 & 44.2 & 34.4 & 2930 \\
\hline $\mathrm{SiO}_{2}$ & $\mathrm{mg} / \mathrm{l}$ & - & - & - & - & - & 0.13 \\
\hline $\mathrm{Fe}_{\text {tot }}$ & $\mathrm{mg} / \mathrm{l}$ & 0.03 & 0.02 & - & 0.09 & - & 0.01 \\
\hline $\mathrm{Mn}_{\text {tot }}$ & $\mathrm{mg} / \mathrm{l}$ & - & - & - & $<0.01$ & - & $<0.01$ \\
\hline $\mathrm{pH}^{2-}$ & & 7.2 & 7.4 & 8.0 & 7.9 & 8.2 & 7.8 \\
\hline${\mathrm{Dry} 105^{\circ} \mathrm{C}}^{2}$ & $\mathrm{mg} / \mathrm{l}$ & - & - & - & 324 & - & 39200 \\
\hline $\mathrm{KMnO}_{4}$ & $\mathrm{mg} / \mathrm{l}$ & 9.5 & 6.3 & - & 6.2 & - & - \\
\hline & & & & & & & \\
\hline
\end{tabular}

more negative parameter $D$, showing a greater influence of $\mathrm{Mg}^{2+}$ concentrations, probably from the dolomite rocks. The diagram of $\mathrm{Al}-2$ shows similarity with the diagram of Al-1. The diagram of sample PA-1 has no resemblance with other diagrams. It is one of the diagrams typical of sandstone aquifers.

\section{MIXING MODEL}

From the results of chemical analyses of $\mathrm{Cl}^{-}$(Tab. 1) and from distribution along the drilling length (Fig. 6), it can be seen that two ranges of $\mathrm{Cl}^{-}$concentrations are present in borehole Lu-1. In the depth interval between $45 \mathrm{~m}$ and $190 \mathrm{~m}$, concentrations are in the range $1210 \mathrm{mg} / \mathrm{l}$ to $1390 \mathrm{mg} / \mathrm{l}$, and in the interval from $500 \mathrm{~m}$ to $801 \mathrm{~m}$, measured concentrations are $6700 \mathrm{mg} / \mathrm{l}$, except in the case of the depth $704 \mathrm{~m}$, where concentration is $6500 \mathrm{mg} / \mathrm{l}$. As one of the end members in the mixing model we have used $\mathrm{Cl}^{-}$concentrations from sample KA-1/22 (Tab. 2) and as another end-member in the mixing model, seawater from Punta Piran was used (Tab. 3). Based on the application of two endmembers, the mixing model proportion of seawater in the depth interval between 0 $\mathrm{m}$ and $190 \mathrm{~m}$ is between $6 \%$ and $6.5 \%$ and in the interval between $500 \mathrm{~m}$ and $801 \mathrm{~m}$ the proportion of seawater is between $30.5 \%$ and $31.0 \%$. The mixing model was also calculated based on salinity data from the end of the pumping test. The results for the proportion of seawater in the groundwater are slightly higher than for the Cl- calculation: the proportion is between $36 \%$ and $38 \%$. 
Tab. 4: Results of seawater chemical analyses and water from borehole Lu-1, June 1994.

\begin{tabular}{|l|c|c|c|c|c|c|}
\hline & & $\begin{array}{c}\text { Borehole } \\
\text { Lu-1 }\end{array}$ & $\begin{array}{c}\text { Sea } \\
\text { F-bottom }\end{array}$ & $\begin{array}{c}\text { Sea } \\
\text { F-surface }\end{array}$ & $\begin{array}{c}\text { Sea } \\
\text { MA-bottom }\end{array}$ & $\begin{array}{c}\text { Sea } \\
\text { MA-surface }\end{array}$ \\
\hline $\mathrm{Cl}^{-}$ & $\mathrm{mg} / \mathrm{l}$ & 6461 & 13487 & 15309 & 16170 & 15897 \\
\hline $\mathrm{SO}_{4}^{2-}$ & $\mathrm{mg} / \mathrm{l}$ & 847 & 2849 & 3034 & 2825 & 2659 \\
\hline $\mathrm{Br}^{-}$ & $\mathrm{mg} / \mathrm{l}$ & 22.1 & 46.8 & 50.1 & 50.4 & 53.7 \\
\hline $\mathrm{HCO}_{3}^{-}$ & $\mathrm{mg} / \mathrm{l}$ & 210 & 112 & 128 & 115 & 138 \\
\hline $\mathrm{pH}$ & & 7.8 & 8.1 & 7.9 & 7.8 & 7.8 \\
\hline
\end{tabular}

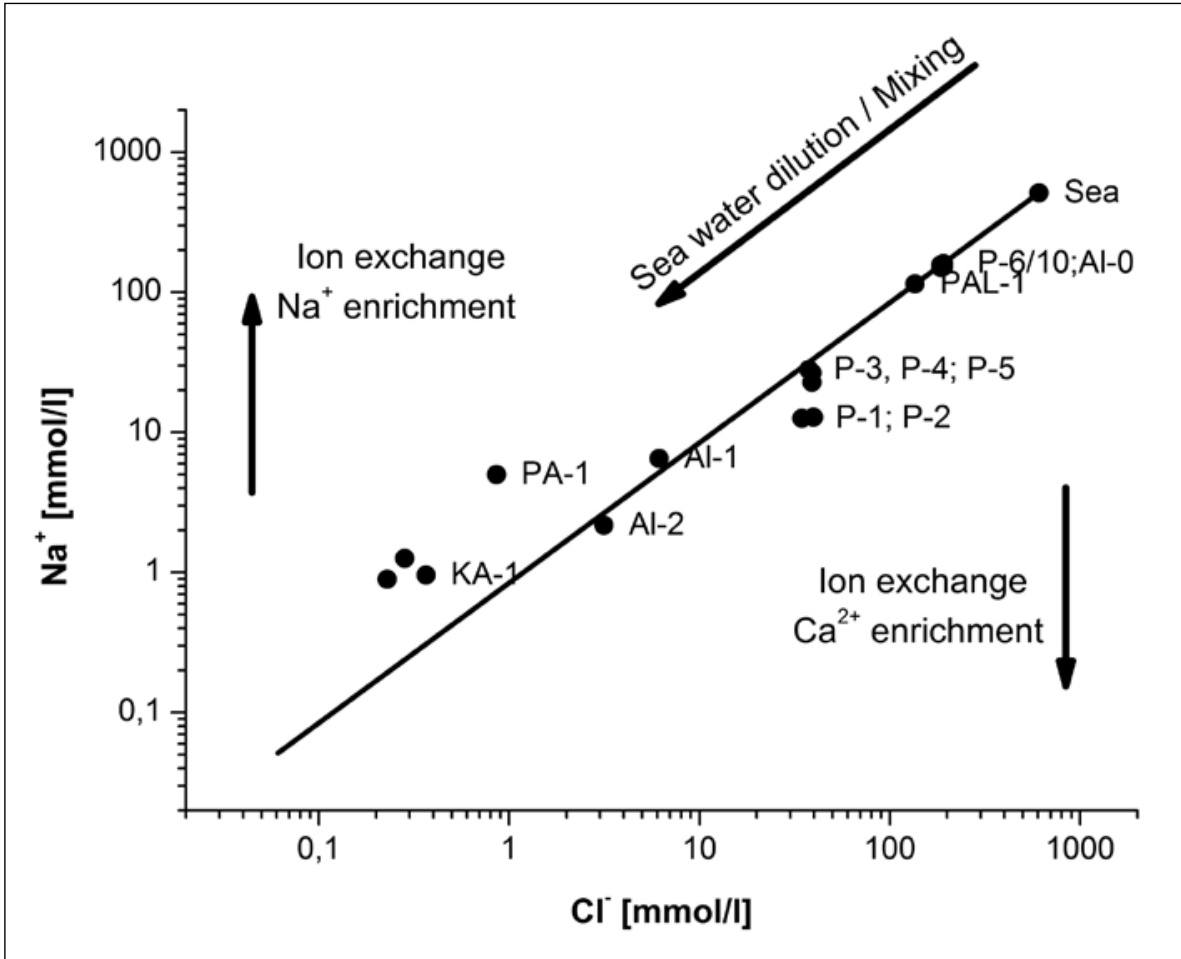

Fig. 7: Mixing model.

The mixing model was also calculated with $\mathrm{Br}$ concentrations as a conservative tracer (e.g. Davis et al. 1998; Kim et al. 2003; Freeman 2007). In the groundwater end member the concentration of $\mathrm{Br}^{-}$is assumed to be much lower than groundwater $\mathrm{Cl}^{-}$concentration and in calculations a concentration of $0 \mathrm{mg} / \mathrm{l}$ was used. The share of seawater based on $\mathrm{Br}^{-}$concentrations is in the range of $41 \%$ to $57 \%$. Discrepancies between calculations of $\mathrm{Br}^{-}$and $\mathrm{Cl}^{-}$are rather large. The reason for this cannot be explained exactly. One possible cause may be inaccuracy of the analytical procedures; the other may be that the geochemistry of the $\mathrm{Br}^{-}$ion differs from that of $\mathrm{Cl}^{-}$, whether as an additional source in the aquifer or as a non conservative tracer. This question must remain open.

\section{ION EXCHANGE PROCESSES}

Seawater-groundwater $\mathrm{mi}-$ xing effects can also be observed in the diagram of the mixing ratio of the whole set of samples (Fig. 7). The line represents the dilution of the original seawater solution and particular samples are represented by dots. Following from the two end member tracer mixing model, $\mathrm{Na}^{+}$and $\mathrm{Cl}^{-}$concentrations at different mixing ratios are distributed along the line. For the samples where this presumption is valid, dots are distributed along the line. If the sample is shifted from the line and if we suppose that seawater is present then this deviation is the consequence of some processes; usually ion exchange appears on the exchangeable sites in clay minerals of the rock or sediment penetrated with seawater (Appelo \& Postma 1993). If the sample is positioned above the line then enrichment of $\mathrm{Na}^{+}$is present; if it is positioned below the line, concentrations of $\mathrm{Na}^{+}$have been depleted. Ion exchange reactions can be presented by the equations:

$$
\begin{aligned}
& \mathrm{CaX}+2 \mathrm{Na}^{+} \leftrightarrow \mathrm{Na}_{2} \mathrm{X}+\mathrm{Ca}^{2+} \\
& \mathrm{CaX}+2 \mathrm{~K}^{+} \leftrightarrow \mathrm{K}_{2} \mathrm{X}+\mathrm{Ca}^{2+} \\
& \mathrm{MgX}+2 \mathrm{Na}^{+} \leftrightarrow \mathrm{Na}_{2} \mathrm{X}+\mathrm{Mg}^{2+} \\
& \mathrm{MgX}+2 \mathrm{~K}^{+} \leftrightarrow \mathrm{K}_{2} \mathrm{X}+\mathrm{Mg}^{2+}
\end{aligned}
$$

where $\mathrm{X}$ represents ion exchange sites in the aquifer minerals. These processes are usually profound when concentrations of cations are higher as is the case in seawater.

Based on the mixing model, samples from borehole Lu-1 are positioned along the line. Shallower samples from the upper part of the borehole (P3, P4 and P5) are slightly shifted down. Samples Al-0, Al-1, Al-2, and PAL-1 are positioned along the line showing that their shares of seawater are $30 \%, 1 \%, 0.5 \%$, and $22 \%$ respectively. 
Tab. 5: Distribution of the ion pattern.

\begin{tabular}{|l|l|l|}
\hline \multicolumn{2}{|l|}{ Cation pattern } & \multicolumn{2}{l|}{ Sequence } & Distribution & Samples \\
\hline 1 & $\mathrm{Na}^{+}>\mathrm{Ca}^{2+}>\mathrm{K}^{+}$ & $\mathrm{P} 3, \mathrm{P} 4, \mathrm{P} 5, \mathrm{P} 6, \mathrm{P} 7, \mathrm{P} 8, \mathrm{P} 9, \mathrm{P} 10, \mathrm{Al}-0, \mathrm{Al}-1, \mathrm{PA}-1, \mathrm{PAL}-1$ \\
\hline 2 & $\mathrm{Ca}^{2+}>\mathrm{Na}^{+}>\mathrm{Mg}^{2+}>\mathrm{K}^{+}$ & $\mathrm{P} 1, \mathrm{P} 2, \mathrm{Al}-2, \mathrm{KA}-1 / 21, \mathrm{KA}-1 / 22$, Rokava, Dragonja-2 \\
\hline 3 & $\mathrm{Ca}^{2+}>\mathrm{Mg}^{2+}>\mathrm{Na}^{+}>\mathrm{K}^{+}$ & $\mathrm{KA}-1 / 1$, Fazan, Koblar, Dragonja-1 \\
\hline 4 & $\mathrm{Na}^{+}>\mathrm{Mg}^{2+}>\mathrm{K}^{+}>\mathrm{Ca}^{2+}$ & sea \\
\hline Anion pattern & \multicolumn{3}{|l}{} \\
\hline 1 & $\mathrm{Cl}^{-}>\mathrm{SO}_{4}{ }^{2-}>\mathrm{HCO}_{3}^{-}$ & $\mathrm{P} 6, \mathrm{P} 7, \mathrm{P} 8, \mathrm{P} 9, \mathrm{P} 10, \mathrm{PAL}-1$, sea \\
\hline 2 & $\mathrm{Cl}^{-}>\mathrm{HCO}_{3}^{-}>\mathrm{SO}_{4}{ }^{2-}$ & $\mathrm{P} 1, \mathrm{P} 2, \mathrm{P} 3, \mathrm{P} 4, \mathrm{P} 5, \mathrm{Al}-0, \mathrm{Al}-1, \mathrm{Al}-2$ \\
\hline 3 & $\mathrm{HCO}_{3}^{-}>\mathrm{SO}_{4}{ }^{2-}>\mathrm{Cl}^{-}$ & $\mathrm{PA}-1$, Dragonja-1, Dragonja-2 \\
\hline 4 & $\mathrm{HCO}_{3}^{-}>\mathrm{Cl}^{-}>\mathrm{SO}_{4}{ }^{2-}$ & $\mathrm{KA}-1 / 21, \mathrm{KA}-1 / 22$ \\
\hline
\end{tabular}

Tab. 6: Hydrogeochemical facies according to Back (1961).

\begin{tabular}{|l|l|l|}
\hline & Facies & Samples \\
\hline 1 & $\mathrm{Ca}^{2+}-\mathrm{Na}^{+}-\mathrm{Cl}^{-}-\mathrm{SO}_{4}{ }^{2-}-\mathrm{HCO}_{3}{ }^{-}$ & $\mathrm{P} 1, \mathrm{P} 2$ \\
\hline 2 & $\mathrm{Na}^{+}-\mathrm{Ca}^{2+}-\mathrm{Cl}^{-}-\mathrm{SO}_{4}{ }^{2-}-\mathrm{HCO}_{3}{ }^{-}$ & $\mathrm{P} 3, \mathrm{P} 4, \mathrm{P} 5, \mathrm{Al}-1$ \\
\hline 3 & $\mathrm{Na}+-\mathrm{Ca}^{2+}-\mathrm{Cl}^{-}-\mathrm{SO}_{4}{ }^{2-}$ & $\mathrm{P} 6, \mathrm{P} 7, \mathrm{P} 8, \mathrm{P} 9, \mathrm{P} 10, \mathrm{PAL}-1, \mathrm{AL}-0$, sea \\
\hline 4 & $\mathrm{Na}^{+}-\mathrm{Ca}^{2+}-\mathrm{HCO}_{3}{ }^{-}-\mathrm{Cl}^{-}-\mathrm{SO}_{4}{ }^{2-}$ & $\mathrm{PA}-1$ \\
\hline 5 & $\mathrm{Ca}^{2+}-\mathrm{Na}^{+}-\mathrm{HCO}_{3}^{-}$ & $\mathrm{KA}-1 / 21, \mathrm{KA}-1 / 22$ \\
\hline 6 & $\mathrm{Ca}^{2+}-\mathrm{Mg}^{2+}-\mathrm{HCO}_{3}^{-}$ & Koblar \\
\hline 7 & $\mathrm{Ca}^{-2}-\mathrm{Mg}^{2+}-\mathrm{HCO}_{3}{ }^{-}-\mathrm{Cl}^{-}-\mathrm{SO}_{4}{ }^{2-}$ & Dragonja-1, Dragonja-2, Fazan \\
\hline 8 & $\mathrm{Ca}^{2+}-\mathrm{Na}^{+}-\mathrm{HCO}_{3}{ }^{-}-\mathrm{Cl}^{-}-\mathrm{SO}_{4}{ }^{2-}$ & Al-2, KA-1/1 \\
\hline
\end{tabular}

deduced from values of the IEB1 parameter; the values for P1 (IEB1=0.6) and P2 (IEB1=0.7) are the highest among analysed samples, showing a high exchange of $\mathrm{Na}^{+}$in seawater with $\mathrm{Ca}^{2+}$ and $\mathrm{Mg}^{2+}$ from the rock. The same can be seen from the molar ratios of $\mathrm{Na}^{+} / \mathrm{Cl}^{-}$, $\mathrm{Ca}^{2+} / \mathrm{Cl}^{-}$, and $\mathrm{Cl}^{-} / \mathrm{HCO}_{3}^{-}$ and the sample position in the Piper diagram, where samples from the upper part of borehole Lu-1 above $190 \mathrm{~m}$ are positioned nearly along the line.

Differences in ion exchange parameters can be the outcome of the low permeability of rocks in the flysch cover and consequently longer retention times inside the rock column. In the samples originating from depths greater than $500 \mathrm{~m}$, ion exchange processes cannot be detected. A possible reason for this is that in limestone where ion exchange reactions are possible only at very long In samples KA-1, PA-1, P1, and P2, deviation from the dilution line is very distinctive. According to the position of borehole KA-1 it can be concluded that groundwater captured by this borehole is not under the influence of the sea and the positions of these samples in the diagram do not reflect ion exchange processes. Sample PA-1 reflects an additional source of $\mathrm{Na}^{+}$, probably clay minerals in the flysch (Tab. 7). This sample has the lowest IBE1 parameter showing high release of $\mathrm{Na}^{+}$and high absorption of $\mathrm{Ca}^{2+}$ and $\mathrm{Mg}^{2+}$. This is also in accordance with the D'Amore diagram showing totally different characteristics of sample PA- 1 .

In the mixing diagram (Fig. 7), the position of Lu-1 samples is the consequence of seawater-groundwater mixing. Differences among particular samples are also observed. Concentrations of $\mathrm{Na}^{+}$in samples $\mathrm{P} 1$ and P2 are lower than expected from the diagram, meaning that some $\mathrm{Na}^{+}$was replaced with $\mathrm{Ca}^{2+}$ or $\mathrm{Mg}^{2+}$ released from the flysch into the solution. From the diagram (Fig. 7), a more intensive ion exchange reaction can be deduced than for samples P3, P4, and P5. The presence of ion exchange reactions can also be residence times and elevated temperatures. In the present aquifer this is not the case.

\section{THERMODYNAMICAL CALCULATIONS}

The results of thermodynamical calculations are given in Tab. 8. It can be clearly seen that samples from the upper part differ from samples from below $500 \mathrm{~m}$. The sharp boundary between the two groups can be clearly seen from TDS calculations. Both groups can also be separated based on the $\mathrm{SI}_{\text {anhydrite }}$ and $\mathrm{SI}_{\text {gypsum }}$ values. The water in the upper parts is more under saturated in gypsum and anhydrite than water from the lower parts. The differences between $\mathrm{SI}_{\text {calcite }}$ and $\mathrm{SI}_{\text {dolomite }}$ are less profound. Over-saturation occurred in all samples with respect to calcite and in all samples except P1 and P2 with respect to dolomite. Values of $\mathrm{SI}_{\text {strontianite }}$ show that groundwater in the deeper parts is in equilibrium with the strontium mineral strontianite.

Eh calculation based on the $\mathrm{Fe}^{2+} / \mathrm{Fe}^{3+}$ ratio proved that strong redox conditions are present in the deeper part of the aquifer. Water is highly over-saturated with 
respect to pyrite. Sample P9 shows slightly higher Eh $(-0.24 \mathrm{~V})$ and lower saturation with respect to pyrite and siderite than sample P10 $(\mathrm{Eh}=-0.28 \mathrm{~V})$, which was taken at the end of the pumping test.

For the silica minerals, over saturation (quartz) or under saturation (amorphous silica) can be observed. It is important to note that saturation indexes for $\mathrm{SI}_{\text {quart }}$ and $\mathrm{SI}_{\text {silicagel }}$ are similar along the depth of the whole borehole. This can be interpreted as a consequence of an $\mathrm{SiO}_{2}$ source in the vicinity of the borehole.

\section{REDOX CONDITIONS IN THE AQUIFER}

Water flowing out from the borehole mouth during the drilling operation has a very strong smell of rotten eggs indicative of $\mathrm{H}_{2} \mathrm{~S}$ gas; sometimes even traces of ammonia can be smelled. Extensive quantities of black amorphous FeS precipitated in the drilling fluid basin. All these phenomena indicated highly reducing conditions in the aquifer, and this was also confirmed by thermodynamical

Tab. 7: Important molar ratios for samples from borehole Lu-1 and Portorož environs.

\begin{tabular}{|l|c|c|c|c|c|c|}
\hline Sample & $\mathrm{Na}^{+} / \mathrm{Cl}^{-}$ & $\mathrm{Ca}^{2+} / \mathrm{Cl}^{-}$ & $\mathrm{Cl}^{-} / \mathrm{HCO}_{3}^{-}$ & $\mathrm{SO}_{4}^{2-} / \mathrm{Cl}^{-}$ & $\mathrm{Ca}^{2+} / \mathrm{Mg}^{2+}$ & $\mathrm{IEB} 1$ \\
\hline P1 & 0.36 & 0.29 & 7.03 & 0.014 & 5.36 & 0.63 \\
\hline P2 & 0.32 & 0.32 & 8.59 & 0.009 & 5.07 & 0.67 \\
\hline P3 & 0.75 & 0.15 & 6.68 & 0.005 & 3.58 & 0.25 \\
\hline P4 & 0.68 & 0.16 & 7.32 & 0.005 & 3.66 & 0.31 \\
\hline P5 & 0.58 & 0.21 & 7.70 & 0.008 & 4.05 & 0.41 \\
\hline P6 & 0.84 & 0.06 & 38.16 & 0.044 & 1.00 & 0.14 \\
\hline P7 & 0.79 & 0.06 & 50.33 & 0.046 & 1.01 & 0.19 \\
\hline P8 & 0.84 & 0.06 & 48.21 & 0.045 & 0.97 & 0.14 \\
\hline P9 & 0.79 & 0.06 & 38.92 & 0.044 & 1.01 & 0.19 \\
\hline P10 & 0.82 & 0.05 & 44.57 & 0.043 & 0.97 & 0.16 \\
\hline Al-0 & 0.81 & 0.05 & 49.69 & 0.000 & 1.31 & 0.19 \\
\hline Al-1 & 1.06 & 0.26 & 1.05 & 0.075 & 1.01 & -0.09 \\
\hline Al-2 & 0.69 & 0.53 & 0.67 & 0.146 & 1.24 & 0.26 \\
\hline KA-1/1 & 2.62 & 3.03 & 0.06 & 0.903 & 0.61 & -1.87 \\
\hline KA-1/21 & 4.46 & 12.02 & 0.03 & 0.133 & 6.80 & -3.64 \\
\hline KA-1/22 & 3.92 & 13.45 & 0.03 & 0.073 & 5.95 & -3.04 \\
\hline PA-1 & 5.83 & 0.34 & 0.18 & 0.925 & 1.20 & -4.98 \\
\hline PAL-1 & 0.85 & 0.07 & 35.53 & 0.061 & 1.24 & 0.13 \\
\hline Fazan & 0.43 & 2.45 & 0.20 & - & 3.83 & 0.54 \\
\hline Koblar & 0.65 & 5.42 & 0.09 & - & 7.22 & 0.28 \\
\hline Rokava & 1.10 & 4.61 & 0.11 & 0.729 & 4.71 & -0.22 \\
\hline Dragonja-1 & 1.21 & 7.78 & 0.06 & 1.661 & 5.39 & -0.27 \\
\hline Dragonja-2 & 1.54 & 5.73 & 0.08 & 1.151 & 3.97 & -0.70 \\
\hline Punta & 0.84 & 0.02 & 232.02 & 0.050 & 0.20 & 0.14 \\
\hline
\end{tabular}

Two groups of waters and big differences in the vertical distribution of $\delta^{18} \mathrm{O}$ values can also be observed in Lu-1 (Fig. 6). They can be used for the determination of the mean altitude of the recharge area. Values of $\delta^{18} \mathrm{O}$ are positively related to air temperature during the precipitation event. According to the well known altitude effect, air temperatures decrease with altitude, and consequently $\delta^{18} \mathrm{O}$ also decreases (Gonfiantini et al. 2001). If the relation between $\delta^{18} \mathrm{O}$ values and altitude is known, the recharge altitude of groundwater can be calculated (Gat 1996).

The information on $\delta^{18} \mathrm{O}$ values from Piranski zaliv is important for the interpretation of $\delta^{18} \mathrm{O}$ values in 
Tab. 8: Equilibria calculations: samples from Lu-1 (performed by WATEQ4F).

\begin{tabular}{|l|c|c|c|c|c|c|c|c|c|c|}
\hline & $P 1$ & $P 2$ & $P 3$ & $P 4$ & $P 5$ & $P 6$ & $P 7$ & $P 8$ & $P 9$ & $P 10$ \\
\hline depth & 43.0 & 65.0 & 91.0 & 113.0 & 190.0 & 500.0 & 611.5 & 704.0 & 800.0 & 800.0 \\
\hline $\mathrm{PCO}_{2}$ & -1.66 & -1.64 & -1.89 & -1.92 & -1.83 & -2.39 & -2.10 & -2.40 & -2.09 & -2.76 \\
\hline TDS & 2315 & 2583 & 2609 & 2634 & 2623 & 12355 & 12105 & 11949 & 12220 & 12255 \\
\hline Carb.Alk. & 4.93 & 4.63 & 5.64 & 5.34 & 5.08 & 5.08 & 3.85 & 3.90 & 4.98 & 4.35 \\
\hline Eh & - & - & - & - & - & - & - & - & -0.24 & -0.28 \\
\hline Anhidrite & -1.89 & -1.97 & -2.51 & -2.40 & -2.15 & -0.98 & -0.94 & -0.97 & -0.94 & -0.99 \\
\hline Calcite & 0.24 & 0.28 & 0.38 & 0.38 & 0.38 & 0.81 & 0.31 & 0.59 & 0.52 & 1.02 \\
\hline Silicagel & -0.74 & -0.78 & -0.83 & -0.83 & -0.83 & -0.78 & - & - & -0.81 & -0.83 \\
\hline Dolomite & -0.27 & -0.16 & 0.19 & 0.20 & 0.17 & 1.75 & 0.75 & 1.33 & 1.17 & 2.18 \\
\hline Gypsum & -1.54 & -1.62 & -2.18 & -2.07 & -1.83 & -0.75 & -0.70 & -0.74 & -0.73 & -0.76 \\
\hline Ilite & -0.48 & -0.66 & -0.66 & -0.60 & -0.58 & -0.53 & - & - & - & - \\
\hline Kaolinite & 1.33 & 1.24 & 0.96 & 0.95 & 0.97 & -0.41 & - & - & - & - \\
\hline Quartz & 0.59 & 0.55 & 0.49 & 0.49 & 0.49 & 0.53 & - & - & 0.48 & 0.48 \\
\hline Pyrite & - & - & - & - & - & - & - & - & 12.80 & 14.06 \\
\hline Siderite & - & - & - & - & - & - & - & - & -0.87 & 1.36 \\
\hline Strontianite & - & - & - & - & - & - & - & - & -0.06 & 0.06 \\
\hline
\end{tabular}

groundwater from Lu-1. In the sample from Punta Piran, the $\delta^{18} \mathrm{O}$ value of $+0.42 \%$ is comparable to average $\delta^{18} \mathrm{O}$ values of $+0.60 \%$ for seawater in Piranski zaliv reported by Herlec (1998). It is also reported that the $\delta^{18} \mathrm{O}$ value for seawater in the Gulf of Trieste is $+0.8 \%$ (Dolenec et al. 1996). In Sečovlje saltpans, $\delta^{18} \mathrm{O}$ values in seawater fluctuate in the range of $-0.8 \%$ to $+5.9 \%$, which is the consequence of evaporation at higher air temperatures and the influence of precipitation (Pezdič et al. 1998). The world average $\delta^{18} \mathrm{O}$ value for seawater is $0.0 \%$ but for closed seas, $\delta^{18} \mathrm{O}$ values are usually slightly positive. For the central part of the Adriatic Sea near Lovrečica, Pezdič (1999) reports a $\delta^{18} \mathrm{O}$ value of $+1.49 \%$ and for the southern part of Adriatic Sea near Bari, $+1.07 \%$. Both values are considerably higher than values measured in the vicinity of Piran. For our end member mixing model calculations of the $\delta^{18} \mathrm{O}$ value reported by Herlec (1998) were taken. However, based on previously mentioned data it is questionable which $\delta^{18} \mathrm{O}$ value is representative for the Piranski zaliv. From the available isotope data and from the geographical and geological position of Piranski zaliv it can be inferred that influences from freshwater on the seawater are considerable. The river Dragonja discharges a substantial amount of surface water to the bay and it is possible that there is an influence of groundwater seeping through the bottom of the sea.

In the end-member mixing model calculations, seawater-groundwater mixing was proposed as reasonable and end-member ratios are the result of pure physical mixing without absorption of the tracer $\mathrm{Cl}^{-}$. In the interpretation of the $\delta^{18} \mathrm{O}$ evolution, the presence of $6 \%$ seawater in the upper part and $31 \%$ in the lower part of the borehole Lu-1 was considered. In the interval between $65 \mathrm{~m}$ and $113 \mathrm{~m}$, two $\delta^{18} \mathrm{O}$ values were used: $-6.31 \%$ o which represents the shallower sample and $-7.18 \%$ o which represents the middle of samples in the interval 91 $\mathrm{m}$ to $113 \mathrm{~m}$. For the interval of $500 \mathrm{~m}$ to $801 \mathrm{~m}$ the $\delta^{18} \mathrm{O}$ value of $-7.45 \%$ was used. The results of mixing model calculation for $\delta^{18} \mathrm{O}$ values of groundwater from the hinterland from the shallower part to the deeper part of the borehole are $-6.75 \%$, $-7.67 \%$, and $-8.59 \%$. These are $\delta^{18} \mathrm{O}$ values that can be observed in the groundwater of the hinterland (Urbanc et al. 1992). The calculated value is also similar to $\delta^{18} \mathrm{O}$ values that were observed in borehole D-1 near Orešje.

The isotopic composition of rainfall during the drilling of Lu-1 is not known. During the course of the years 2001 and 2003, investigation of stable isotope composition in the precipitation in the area was performed (Vreča et al. 2007), showing that for Portorož airport, positioned $2 \mathrm{~m}$ above sea level, the monthly average weighted $\delta^{18} \mathrm{O}$ value is $-5.3 \%$, ranging between $-0.9 \%$ and $-10.9 \%$. For the evaluation of the altitude effect in the hinterland, data from the same period from the precipitation station Kozina positioned at $497 \mathrm{~m}$ can be used. In this station the monthly average weighted $\delta^{18} \mathrm{O}$ value is $-7.6 \%$ with the range between $12.3 \%$ and $-2.1 \%$. The calculated mean altitude effect between Porotorož and Kozina precipitation station for the period between 2002 and 2003 is $0.46 \% / 100 \mathrm{~m}$, which is very high. Values reported in the literature range between $0.16 \%$ o $/ 100 \mathrm{~m}$ and $0.4 \% \mathrm{~m} / 100 \mathrm{~m}$ and are only exceptionally higher (e.g. Sigenthaler \& Oeschger 1980; Doctor 2008). For the same area and for the earlier and more sporadic observations between 2001 and 2003, altitude effects are reported between $0.27 \% 0 / 100 \mathrm{~m}$ and $0.33 \% / 100 \mathrm{~m}$ (Vreča et al. 2005). High altitude effects are also reported for the Alpine area of Northern Italy (Longinelli \& Selmo 2003) and for the Dinaric mountain range from Slovenia to Croatia (Vreča et al. 2006), 
with values around $0.30 \% / 100 \mathrm{~m}$. The altitude effect is not dependent only on the relief but also depends on the prevailing weather situation and especially on the amount of precipitation. However, it can be seen that due to high relief alteration over short distances and due to the mixing of various air masses (Vreča et al. 2007), altitude effects in the hinterland region of Portorož are higher than those reported elsewhere.

To determine the highest possible altitudes of the recharge area, the highest altitude effect of $0.46 \% / 100 \mathrm{~m}$ was used. Based on this gradient and on the altitude $\delta^{18} \mathrm{O}$ value equation reported by Vreča et al. (2007) the mean altitudes of the recharge areas are $314 \mathrm{~m}, 512 \mathrm{~m}$, and $710 \mathrm{~m}$ respectively. The question of whether the estimated altitudes are physically possible can be raised. According to the high relief of the hinterland and based on the geological structure (Placer 1981, 2005, 2007), the calculated recharge areas are physically possible. In the near vicinity to the north, flysch hills with altitudes of up to $400 \mathrm{~m}$ are present. To the northeast in the area of Podgorje kras the altitudes range between $400 \mathrm{~m}$ and 600 $\mathrm{m}$ and more to the north on the line between Kozina and Slavnik, the altitude reaches over $1000 \mathrm{~m}$.

The problem of the hydrogeochemical interpretation of waters from borehole $\mathrm{Lu}-1$ is also reflected by the fact that the age of groundwater is not known. Relatively negative values of $\delta^{18} \mathrm{O}$ can be the result of older groundwater ages when isotopic composition of precipitated water was more negative. Based on available data this cannot be proved. Transmissivity values of the carbonate aquifer are high and groundwater is well homogenised, especially in deeper parts below $500 \mathrm{~m}$. With much older ages of the groundwater with more negative $\delta^{18} \mathrm{O}$ values, a more pronounced ion exchange reaction could be observed in the deeper part of the aquifer; however we think that this is not the case. Interpretation is more complicated for shallower groundwater where exchange reactions are more explicit. The sample from the depth of $43 \mathrm{~m}$ is probably the result of recharge from the near vicinity of the borehole and the more negative $\delta^{18} \mathrm{O}$ value is the result of longer residence time due to low rock permeability. For samples between $91 \mathrm{~m}$ and $113 \mathrm{~m}$, higher recharge areas are more probable because in this interval more permeable layers may appear and there may be better homogenisation of groundwater.

\section{REGIONAL HYDROGEOLOGICAL INTERPRETATION}

Based on the interpretation of chemical and isotope analyses of groundwater originating from borehole Lu-1 and groundwater from the Portorož environs and with the help of the mixing model, we propose the following regional hydrogeological interpretation. In the area of south-western Slovenia, deep and extensive groundwater flow in the direction from the northeast to the southeast is present. This flow is recharged in the wider area of Matarsko podolje, Slavnik ridge, and Kraški rob and flows to the eastern part of Trieste Bay (Fig. 1). In a similar manner, submarine springs of Izola could be interpreted as well as Rižana spring, which is recharged in Matarsko polje (Krivic et al. 1989), representing high groundwater overflow from the deep aquifer structures.

\section{CONCLUSIONS}

Artesian borehole Lu-1 is $801 \mathrm{~m}$ in depth and sited very close to the sea in Lucija near Portorož (Piranski zaliv), and was drilled in 1994. It was constructed through the $257 \mathrm{~m}$ deep sequence of flysch rocks after which it enters limestone of Palaeogene and Cretaceous age. The aquifer where the borehole is constructed is classified as high yield and highly permeable confined carbonate aquifer with fissured porosity.

Groundwater samples were collected during drilling and final pumping tests after borehole completion. The results of these analyses were compared with groundwater samples from the wider Portorož environs. It was established that groundwater in the well Lu-1 is a result of seawater-groundwater mixing and due to the presence of high organic matter content in the aquifer is subject to highly reducing conditions. Groundwater from the carbonate aquifer is over saturated with respect to calcite, dolomite, iron sulphides, and iron carbonate, with the presence of $\mathrm{H}_{2} \mathrm{~S}$ and $\mathrm{NH}_{4}^{+}$. In the carbonate aquifer, 33\% seawater is estimated by the mixing model, and in the flysch part, $6 \%$ seawater is represented.

In the shallower part of the borehole $\mathrm{Ca}^{2+}-\mathrm{Na}^{+}-$ $\mathrm{Cl}^{-}-\mathrm{SO}_{4}^{2-}-\mathrm{HCO}_{3}^{-}$hydrogeochemical facies is present followed by $\mathrm{Na}^{+}-\mathrm{Ca}^{2+}-\mathrm{Cl}^{-}-\mathrm{SO}_{4}{ }^{2-}-\mathrm{HCO}_{3}{ }^{-}$facies and in the deepest carbonate part of the borehole $\mathrm{Na}^{+}-\mathrm{Ca}^{2+}-\mathrm{Cl}^{-}$ $-\mathrm{SO}_{4}^{2-}$ facies is present. Based on the comparison with other boreholes a similar stratification is interpreted to exist in the whole coastal aquifer around Portorož. The 
transition from groundwater to seawater is gradual and stratified. Hydrogeochemical stratification is related to the geological structure with differences in physical and chemical properties between flysch and limestone rocks.

It is shown by $\delta^{18} \mathrm{O}$ values that fresh groundwater is recharged from the hinterland. We conclude that in the area of south-western Slovenia deep and extensive groundwater flow in the direction from the northeast to the southeast exists and discharges as submarine seepage into the eastern part of the Gulf of Trieste. Above this regional groundwater flow, many local perched aquifers exists with a different hydrogeochemistry that is mainly controlled by a simple $\mathrm{Ca}^{2+}-\mathrm{Mg}^{2+}-\mathrm{CO}_{2}-\mathrm{H}_{2} \mathrm{O}$ open system.

The chemical analyses presented in this paper are not part of a systematic sampling plan. They are the result of applied hydrogeological research in various boreholes in the wider Portorož environs during the years 1993 and 1994. Some determinations of dissolved species are not directly comparable; they differ according to the analytical methods, sampling procedures, and detection limits. An additional problem for the analytical procedures is the high contrast in dissolved species concen- trations, especially high concentrations of $\mathrm{Cl}^{-}$, which can greatly influence other species determinations. In such cases, the results of chemical analyses must be treated as semi-quantitative. However, in spite of all the drawbacks connected with the inconsistent sampling plan and various levels of analytical accuracy, the hydrogeochemical results together with stable isotope measurements of $\delta^{18} \mathrm{O}$ show a consistent picture of the hydrogeological conditions in the carbonate coastal aquifer of the Slovene maritime province.

In the carbonate aquifer of Portorož and its environs many research questions are remain open. In the future more systematic sampling based on the consistent plan should be performed. This will present firm basis for the investigation of hydrogeochemical processes in the transition zone of seawater groundwater mixing inside of limestone aquifer rich with organic mater. More detailed investigations are needed to determine the age of groundwater at the different depths and parts of the aquifer, as well as recharge zone and its altitude. For this purpose several different investigation methods must be used, including stable and radioactive methods in the combination with organic and inorganic geochemistry.

\section{ACKNOWLEDGEMENTS}

The paper is dedicated to the late Miha Marinko, leader of the borehole Lu-1 project. The help of Andrej Lapajne, Polona Vreča and Simon Mozetič during the preparation of the article is greatly appreciated. Part of the research in 1994 was financed by Metropol hoteli d.d. The article was prepared through the research programme "Groundwater and Geochemistry" of the Geological Survey of Slovenia and financially supported by the Slovene Research Agency, ARRS.

\section{REFERENCES}

Appelo, C.A.J. \& D. Postma, 1993: Geochemistry, Groundwater and Pollution.- A.A. Balkema, pp. 536, Rotterdam.

Back, W., 1961: Techniques for mapping of hydrochemical facies.- U.S. Geological Survey Professional Paper, 424-D, 380-382.

Bear, J., 1979: Hydraulics of Groundwater-- McGraw-Hill, pp. 569, New York.

Bonacci, O., 1995: Brackish karst spring Pantan (Croatia).- Acta Carsologica, 24, 99-107.

Breznik, M., 1973: Nastanek zaslanjenih kraških izvirov in njihova sanacija.- Geologija, 16, 83-186.

Breznik, M., 1998: Storage Reservoirs and Deep Wells in Karst Regions.- A.A. Balkema, pp. 251, Rotterdam.
Breznik, M. \& F. Steinman, 2008: Hydromechanism and desalination of coastal karst aquifers: theory and cases.- Acta Carsologica, 37, 197-212.

Calaforra, J.M. (ed.), 2004: The Main Coastal Karstic Aquifers of Southern Europe.- European Comission, Directorate General for Research, pp. 123, Brussels.

D’Amore, F., Scandiffio, G. \& C. Panichi, 1983: Some observation on the chemical classification of ground waters.- Geothermics, 12, 141-148.

Davis, S.N., Whittemore, D.O. \& J. Fabryka-Martin, 1998: Uses of cloride/bromide ratios in studies of potable water.- Ground Water, 36, 338-350. 
Doctor, D.H., 2008: Hydrologic connections and dynamics of water movement in the classical Karst (Kras) aquifer: evidence from frequent chemical and stable isotope sampling.- Acta Carsologica, 37, 101-123.

Dolenec, T., Pezdič, J. \& U. Herlec, 1996: Stable isotope study of the Adriatic Sea.- Acta Geologica Hungarica, 39, Suppl. 35-38.

Domenico, P.A. \& F.W. Schwartz, 1990: Physical and Chemical Hydrogeology.- John Wiley \& Sons, Inc., pp. 824, New York.

Faganeli, J., Ogrinc, N., Walter, L.N. \& J. Žumer, 2005: Geochemical characterization of the submarine spring of Izola (Gulf of Trieste, N Adriatic Sea).RMZ - Materials and Geoenvironment, 52, 35-39.

Fistanić, I., 2006: Sustainable management of brackish karst spring Pantan (Croatia).- Acta Carsologica, 35, 65-72.

Fleury, P., Bakalowicz, M. \& G. de Marsily, 2007: Submarine springs and coastal karst aquifers: A review.Journal of Hydrology, 339, 79-92.

Freeman, J.T., 2007: The use of bromide and chloride mass ratios to differentiate salt-dissolution and formation brines in shallow groundwaters of the Western Canadian Sedimentary Basin.- Hydrogeology Journal, 15, 1377-1385.

Gat, J.R., 1996: Oxygen and hydrogen isotopes in the hydrologic cycle.- Annual Review of Earth and Planetary Sciences, 24, 225-262.

Gonfiantini, R., Roche, M.A., Olivry, J.C., Fontes, J.C. \& G.M. Zuppi, 2001: The altitude effect on the isotopic composition of tropical rains.- Chemical Geology, 181, 147-167.

Hem, J.D., 1985: Study and interpretation of the chemical characteristics of natural waters.- U.S. Geological Survey Water Supply Paper, 2254, pp. 256.

Herlec, U., 1998: What can we learn from the stable oxygen isotope composition of recent molluscs from the Adriatic sea: the problem of mean annual marine water temperature.- RMZ - Materials and Geoenvironment, 45, 51-55.

Kim, Y., Lee, K.S., Koh, D.C., Lee, D.H., Lee, S.G., Park, W.B., Koh, G.W. \& N.C. Woo, 2003: Hydrogeochemical and isotopic evidence of groundwater salinization in a coastal aquifer: a case study in Jeju volcanic island, Korea.- Journal of Hydrology, 270, 282-294.

Konhauser, K., 2007: Introduction to Geomicrobiology.Blackwell Publishing, pp. 425, Malden.

Krivic, P., Bricelj, M. \& M. Zupan, 1989: Podzemne vodne zveze na področju Čičarije in osrednjega dela Istre (Slovenija, Hrvatska, NW Jugoslavija).Acta Carsologica, 18, 265-295.
Kuščer, I., 1950: Kraški izviri ob morski obali.- Razprave - Razred za matematične, fizikalne in tehnične vede, 1, 99-147.

Kuščer, I. \& D. Kuščer, 1964: Observations on brackish karst sources and sea swallow - holes on the Yugoslav coast.- In: Haralambos, D., (ed.) Association Internationale des Hydrogeologues Memoires Tome V: Reunion d'Athenes 1962. Greek Institute for Geology and Subsurface Research, pp. 344-353, Athenes.

Lapanje, A. \& J. Prestor, 2003: Leau thermale dans les calcaires Paléogènes et Crétacés de la côte slovene.- In: Circulations Hydrothermales en Terrains Calcaires, pp. 31-38, Carcassonne.

Longinelli, A. \& E. Selmo, 2003: Isotopic composition of precipitation in Italy: a first overall map.- Journal of Hydrology, 270, 75-88.

Marinko, M., 1994: Poročilo o opravljenih delih na vrtini Lu-1 v Portorožu. Inštitut za geologijo, geotehniko in geofiziko, Report.

Petrič, M., Kogovšek, J. \& L. Ballarin, 2004: Coast of Trieste and Kras (Italy - Slovenia).- In: Calaforra, J.M. (ed.): The Main Coastal Karstic Aquifers of Southern Europe. European Comission, Directorate General for Research, pp. 46, Brussels.

Pezdič, J., 1999: Izotopi in geokemijski procesi.- Naravoslovnotehniška fakulteta, Oddelek za geologijo, pp. 269, Ljubljana.

Pezdič, J., Dolenec, T., Faganeli, J., Čermelj, B., Vukovič, A. \& N. Ogrinc, 1998: Water evaporite effects on stable isotopes in the salt pans of Sečovlje (Slovenia).- RMZ - Materials and Geoenvironment, 45, 145-148.

Piper, A.M., 1944: A graphic procedure in the geochemical interpretation of water analysis.- Transaction of American Geophysical Union, 25, 914-923.

Placer, L., 1981: Geološka zgradba jugozahodne Slovenije.- Geologija, 24, 27-60.

Placer, L., 2005: Structural curiosity of the northern Istria.- Geologija, 48, 245-251.

Placer, L., 2007: Kraški rob (landscape term), Geologic section along the motorway Kozina - Koper (Capodistria).- Geologija, 50, 20-44.

Pleničar, M., Polšak, A. \& D. Šikić, 1973: Osnovna geološka karta SFRJ 1:100.000. Tolmač za list Trst.Zvezni geološki zavod, pp. 68, Beograd.

Plummer, L.N., Jones, B.F. \& A.H. Truesdell, 1976: WATEQF - A Fortran version of WATEQ, A computer program for calculating chemical equilibria of natural waters.- U.S. Geological Survey Water Resources Investigations Report, 76-13, pp. 70.

Schoeller, H., 1962: Les eaux souterraines.- Masson \& Cie, pp. 642, Paris. 
Siegenthaler, U. \& H. Oeschger, 1980: Correlation of ${ }^{18} \mathrm{O}$ in precipitation with temperature and altitude.- $\mathrm{Na}$ ture, 285, 314-317.

Snyder M., Taillefert, M. \& C. Ruppel, 2004: Redox zonation at the saline-influenced boundaries of a permeable surfical aquifer: effects of physical forcing on the biogeochemical cycling of iron and manganese.- Journal of Hydrology, 296, 164-178.

Surić, M., Jalžić, B. \& D. Petricioli, 2007: Submerged speleothems - expected the unexpected. Examples from the eastern Adriatic coast (Croatia).- Acta Carsologica, 36, 389-396.

Todd, D.K. \& L.W. Mays, 2005: Groundwater Hydrology.John Wiley \& Sons, Inc., pp. 636, New York.

Tulipano, L. Fidelibus, M.D. \& A. Panagopoulos, (eds.), 2005: Groundwater Management of Coastal Karstic Aquifers.- COST Office, pp. 363, Brussels.

Urbanc, J., Pezdič, J., Juren, A. \& J. Prestor, 1992: Isotopic study of relation between the Rižana spring and waters from its vicinity.- In: Hötzl, H. \& A. Werner, (eds.): Tracer Hydrology: Proceedings of the $6^{\text {th }}$ International Symposium on Water Tracing, Karlsruhe (Germany) A.A. Balkema, 295-298, Rotterdam.

Urbanc, J., Marinko, M., Kogovšek, J. \& M. Petrič, 2004: Izola.- In: Calaforra, J.M. (ed.): The Main Coastal Karstic Aquifers of Southern Europe. European Comission, Directorate General for Research, 47, Brussels.
Vreča, P., Kanduč, T., Žigon, S. \& Z. Trkov, 2005: Isotopic composition of precipitation in Slovenia. In: Isotopic Composition in Precipitation in the Mediterranean Basin in Relation to Air Circulation Patterns and Climate, TECDOC Series No. 1. 1453, IAEA, pp. 157-172, Vienna.

Vreča, P., Krajcar Bronić, I., Horvatinčić, N. \& J. Barešić, 2006: Isotopic characteristics of precipitation in Slovenia and Croatia: Comparison of continental and maritime stations.- Journal of Hydrology, 330, 457-469.

Vreča, P., Brenčič, M. \& A. Leis, 2007: Comparison of monthly and daily isotopic composition of precipitation in coastal area of Slovenia.- Isotopes in Environmental and Health Studies, 43, 307-321.

Vrhovec, T., Mihevc, A., Lauritzen, S.E. \& J. Lundberg, 2001: O starosti potopljenih stalaktitov v potopljeni jami pri otočku Galiola, Dalmacija, Hrvatska.- Naše jame, 43, 31-36.

Wicks, C.M. \& J.S. Herman, 1996: Regional hydrogeochemistry of a modern coastal mixing zone.- Water Resources Research, 32, 401-407.

Žumer, J., 2004: Odkritje podmorskih termalnih izvirov pred Izolo.- Geografski obzornik, 51, 11-17.

Žumer, J., 2008: Podmorski kraški izviri pred Izolo.Naše jame, 47, 39-44. 